\title{
Identifying design criteria for urban system 'last-mile' solutions - a multi-stakeholder perspective
}

\author{
Tomás Seosamh Harrington ", Jagjit Singh Srai, Mukesh Kumar, Josef Wohlrab \\ Centre for International Manufacturing, Institute for Manufacturing, Engineering Department, \\ School of Technology, University of Cambridge, UK \\ *Corresponding author email: tsh32@cam.ac.uk
}

\begin{abstract}
This study presents a novel approach to designing and evaluating 'last-mile' solutions encompassing the social and economic perspectives of key stakeholders. While urban system initiatives have been implemented in practice, theoretical gaps remain at the operational design level. A theoretical framework is developed, based on design criteria identified from a critical synthesis of supply chain and operations management literature, and 'operationalised' using an in-depth case study demonstrating implementation of a Consumer Choice Portal-Package Consolidation Centre solution, within a densely populated urban geography.

Findings suggest that there is a need to re-define the role of institutional actors beyond that of the traditional governance task, to one of being able to facilitate performance outcomes. Similarly, industrial efficiency dimensions need to be re-orientated to include consumer participation, social considerations and multi-stakeholder service outcomes. Finally, implications for operations theory and practising managers in city logistics are highlighted, with suggested directions for future research.
\end{abstract}

\section{Introduction}

The urban 'last-mile' in logistics and distribution systems is becoming increasingly complex and strategic for manufacturers as well as retailers. With increasing transportation costs and longer leadtimes, it is also recognised as the most critical element to manage, contributing as much as $75 \%$ of total supply chain costs (Boyer, Frohlich and Hult, 2004). Increased pollution levels and congestion are also an issue, with transport accounting for $24 \%$ of total $\mathrm{CO}_{2}$ emissions, urban areas responsible for $80 \%$ of on-road emissions growth since 1980 , and for $63 \%$ of total 2012 emissions. (UN-HABITAT, 2009; Gately, Hutyra, and Wing, 2015). In response, EU transport policies are looking to phase out conventionally fuelled vehicles in urban centres by 2050; halving their usage, and moving towards 'zero emissions' by 2030 (LaMiLo, 2015). With future projections that $70 \%$ of the World's population will be living in cities by 2050 (UN-HABITAT, 2015), social, economic, and environmental pressure to develop innovative solutions is originating from planners and regulators, who are placing more restrictions on the movement of stock, goods and freight (DfT, 2015).

In the provision of 'last-mile'-type solutions, traditional city operations have been predominantly assessed from the industrial point-of-view, mainly focusing on the reduction of distribution costs, often neglecting the increasing complexity, and desired 'service outcomes' of all stakeholders within a specific urban system (Taniguchi and Tamagawa, 2005). Supply chain decisions are typically taken in order to achieve commercial efficiency, disregarding wider environmental objectives, resulting in city authorities having to balance diverging private sector objectives and social ones (Danielis, Maggi, Rotaris and Valeri, 2012). The issue of failed deliveries is specifically targeted here, as UK logistics providers report that $30 \%$ of small packages dispatched to customer homes fail to be delivered first time, resulting in poor customer service and avoidable logistics inefficiencies (Fernie and McKinnon, 2004). This, in turn, results in large numbers of repeat delivery runs exacerbating urban congestion, pollution and accident levels. For the general public, there are 
significant negative environmental and societal impacts caused by the increased numbers of vehicles (up 17\% in 2015, according to the Society of Motor Manufacturers and Traders), which are often unsuitable for specific urban areas. Consumers are aware that deliveries to their home may fail repeatedly, however, limited mechanisms currently exist to better engage with the urban supply chain, such as enabling a consumer to make informed decisions regarding the mode of 'last-mile' delivery, and to take control of timing, cost, reliability and 'greenness' (Srai and Harrington, 2014). The potential for impact is vast, given that the total UK postal services market was valued at £14bn in 2013, generating approximately $£ 7 \mathrm{bn}$ in revenues which included $£ 6.6 \mathrm{bn}$ in courier and express delivery items (FT, 2013). Furthermore, both complexity and UK parcel volumes are projected to grow at circa $3 \%$ per annum, from approximately $1.7 \mathrm{bn}$ units in 2013, to 2.3bn units by 2023 (PWC, 2013).

Recent years have witnessed the development of new 'routes-to-market' involving specialist 'last-mile' consolidation and distribution service providers, coupled with the exponential rise of directto-consumer business delivery (Boyer, Prud'homme, and Chung, 2009; Srai and Harrington, 2014). Changing consumer behaviour has had a dramatic effect on consumption patterns, as the general public move more towards actively assessing the environmental impacts of the products and services they purchase (Montoya-Torres, Gutierrez-Franco, and Blanco, 2014; Srai and Harrington, 2014; MIT, 2014). The continuing rapid development of digital supply chains has driven the need for improved service delivery, highlighting the many challenges and problems inherent within the logistics system, and a subsequent need for optimisation (Srai and Harrington, 2014).

While recent studies have demonstrated that a structured consultation process, to introducing and trialling initiatives aimed at increasing the sustainability of urban supply chains, can be beneficial, actual evaluation is dependent on many aspects that may well emerge well after the initial consultation (Österle, Aditjandra, Vaghi, Grea, and Zunder, 2015). The approach presented here focuses on a critical theoretical gap at the operational design level, and provides a unique approach to designing and evaluating urban system 'last-mile' solutions - encompassing both social and economic perspectives of all stakeholder groups. The methods developed, as part of this study, look to inform the development of a common set of measures (at the outset for design, implementation and evaluation stages) for specific 'last-mile' solutions, in order to estimate performance in design stages, and measure 'actual' performance in post-implementation stages. No construct currently exists which shows the relationship between the different measures and, therefore, between the interests of the different stakeholders. Hence, the primary research question, we look to address, is to determine what are the key design criteria - from a multi-stakeholder perspective - that are applicable to urban system 'last-mile' operations.

A theoretical framework for the design and evaluation of 'last-mile' logistics solutions is developed, based on a set of design criteria - derived from both academic literature, and examples of existing urban system solution implementations - and an in-depth case study that involves the design, set-up and operation of a Consumer Choice Portal (CCP) and Package Consolidation Centre (PCC). Our work proposes a comprehensive and balanced approach to solution design and evaluation, within a pre-defined urban system, capturing the critical stakeholders and their individual and overlapping interests. This framework looks to challenge the traditional design and planning of city logistic systems, improving the efficiency of flow (e.g. the probability of goods arriving on time) and minimising disruption (e.g. delays, congestion), by bringing more of an element of consumer participation, and social externalities.

The paper is structured as follows: section 2 first reviews the literature and presents a definition of the urban system 'last-mile' and associated characteristics. Key stakeholder classification, and the identification and categorisation of proposed design criteria for each stakeholder group are then summarised. These categories of literature support the case investigation, with the output being a theoretical framework. Section 3 next describes the methodological approach to framework development and its role in guiding management of the process. Section 4 presents a summary of the case study results, organised in conjunction with the categories of public-private institutional themes presented in section 2. Finally, section 5 discusses conclusions and directions for future research. 


\section{Literature review}

The academic literature reports several examples of innovative 'last-mile' concepts - on-line retail delivery (Esper, Jensen, Burton and Turnipseed, 2003), on-line groceries (Boyer, Frohlich and Hult 2005) and urban freight consolidation (Browne, Sweet, Woodburn and Allen, 2005) - but often from the 'industrial' (commercial efficiency) perspective of the 'supplier'. Previous research also suggests empirical criteria for green supply chain performance measurement, while being operational in nature, are mostly specific to a focal company, and neglect broader environmental and social objectives (Gimenez and Tachizawa, 2012; Kumar Dey and Cheffi, 2013; Österle et al, 2015). From an operations management perspective, decisions often remain firmly based on transaction costs and risk, when future innovative solutions call for alternative performance indicators, and operational criteria to better assess capabilities (Björklund, Martinsen and Abrahamsson, 2012; Kumar and Gregory, 2013).

Given the amount and complexity of potential attributes, the following sub-sections look to identify the most important factors - which may inform the key contextual elements, critical overlapping interests, and 'touch points' of the different types of stakeholders (Rodrigue, Comtois and Slack, 2009; Harrington, Srai and Christodoulou, 2014; Harrington and Srai, 2016a).

\subsection{Defining the 'urban system last-mile’}

Specific 'urban system' characteristics have a significant impact on the performance of a 'last-mile' solution. For example, delivery in areas with higher customer densities should be less expensive, with wider delivery windows facilitating greater delivery efficiencies (Chopra, 2003; Boyer et al., 2009). In this paper, we extend 'urban system' terminology - used to define and describe both the system and dynamics of cities and towns, and the economic and social functions of urban settlements of different sizes (Martin, 2000) - to a service logistics context, which we define as the management of activities, which respond to customers on an individual basis (Davis and Manrodt, 1994). As the focus of the case study features end-consumers located in a specific urban area, our definition of a 'supply chain' includes the 'last-mile' distribution system that delivers the goods to/in the complex environment, that is a town or a city (Danielis et al., 2012). This complexity stems largely from a lack of integration - with multiple firms, often with their individual systems, activities, technologies, information and resources, delivering their product or a service to an end customer (ibid). Hence, the term 'urban supply chain' identifies that part of a supply chain responsible for parcel delivery to a pre-defined urban geography. Furthermore, we consider the 'last-mile' to be the last part of the physical goods delivery process, which involves a set of activities that are necessary for the delivery process, and involves the last transit point to the final drop point of a delivery chain (Harrington, Wohlrab and Srai, 2012; Aized and Srai, 2013).

Hence, a working definition of the urban system 'last-mile', in the context of this study, is proposed to be "the final component of a B2C delivery process. It takes place within a pre-defined urban system, with specific characteristics, and includes upstream logistics to the last transit point until the destination point of a delivery. It involves a series of activities and processes, of critical value to all the involved stakeholder groups, within an urban system".

\subsection{Key stakeholders within an urban system 'last-mile'}

Critical to any framework development is the involvement of stakeholders, during the whole project cycle, from concept to project planning and implementation, to monitoring and evaluation (Österle et al, 2015). Hence, a key consideration is to understand the role that the network of key institutional, industrial and supply network actors may play in the development and implementation of alternative business models, and in successfully commercialising a solution (Harrington and Srai, 2016b). The 
network actors will have various perspectives, requirements, and objectives, in defining the different roles, inter-relationships and governance structures (i.e. the system of rules, practices and processes by which interests of the key network stakeholders will be directed and controlled), and in forming the basis for 'last-mile' solution evaluation. Here, we categorise the main stakeholders, within the 'lastmile' of a specific urban system - as a means of reducing evaluation complexity, and ensuring clarity with respects to the constructs presented.

Taniguchi and Tamagawa (2005) previously considered stakeholder behaviour in the context of the 'last-mile'. In total, four key stakeholders were derived as shippers, freight carriers, consumers and administrators (Taniguchi, Thompson and Yamada, 2001; Taniguchi and Tamagawa, 2005). In turn, Russo and Comi (2011) proposed three stakeholder groups, namely, end-consumers, transportation operators, and public administration. For this study, three stakeholder groups are defined as Institutional, Industrial and Consumer. 'Institutional' relates to the local and regional authorities, within the specific geographical area that the CCP-PCC operates in. Shippers, freight carriers and local couriers are viewed as 'Industrial' entities, with similar objectives and interests, in reducing costs while meeting customer needs. 'Consumer' incorporates customers of the CCP-PCC where the PCC is in operation. A literature categorisation framework of stakeholders, within an urban system, is now developed in sections 2.3-2.6, with the aims of capturing the following:

- Individual perspectives, requirements, objectives and interests of the different stakeholder groups: Consumer, Industrial and Institutional.

- Common interests and trade-offs between the stakeholder groups: Industrial-Institutional, Consumer-Institutional and Industrial-Consumer

- Industrial-Consumer-Institution common interest and trade-offs (3-way perspective on the urban system 'last-mile')

\subsection{Designing 'last-mile’ solutions from a multi-stakeholder perspective}

In order to facilitate broader stakeholder involvement in future city and urban supply chain policymaking (Graham, Coles and Mehmood, 2015), the approach employed in this paper builds on 'multi-organisational network' (MON) concepts previously reported (Srai 2011; Harrington, Kirkwood and Srai, 2012) which capture critical 'touch points' between organisations and end-customers (Harrington and Srai, 2016a), in order to promote greater cooperation within a specific urban system.

Entities, seeking to develop 'last-mile' solutions, are often impeded by their inability to engage effectively with a wider network, where they may need to draw on external support (Sarasvathy and Dew, 2005; Rossi, Colicchia, Cozzolino and Christopher, 2013). The multiple stakeholders involved in e-tailing, conventional retail, parcel delivery and transport systems within a particular geography is complex, with multiple (yet unrealised) opportunities for data sharing and systems integration (Stefansson, 2002; Yu, 2015). Service initiatives, in customer relationship management, regularly fail due to a lack of network integration and customer orientation, attributed to a lack of clarity on network objectives, poor design and planning, and the use of misleading measures or improper measurement approaches (Jain, Jain and Dhar, 2007; Foss, Stone, and Ekinci, 2008). Failure to incorporate such requirements may be detrimental to the design of a 'last-mile' solution, resulting in many 'smart city' operational initiatives failing to proceed to the implementation phase, because the environmental and social benefits cannot be effectively (or correctly) evaluated.

Marshall, McCarthy, Heavey, and McGrath (2015) examined a series of constructs to explain integration or trade-offs between different 'types' of sustainability, and highlighted a gap in how environmental and social supply chain sustainability practices are evaluated. In addition, no collaborative construct currently exists that shows the relationship between the different economic, social and operational measures, and interests of all stakeholders within an urban area. This lack of alignment, with respect to stakeholder perspectives is a critical issue, as highlighted by the MIT Center for Transportation \& Logistics (MIT CTL) survey study on freight traffic congestion causes and solutions involving public and private sectors (Caplice and Phadnis, 2014). A series of 'enablers', 
largely relational and involving collaborative and qualitative aspects (rather than just cost and quantitative measures), are shown to provide greater clarity on overall network objectives (i.e. defined common goals for a network of partners) - and avoid the use of misleading measures or improper measurement approaches (Hervani, Helms and Sarkis, 2005; Lehtinen and Ahola, 2010; Harrington et al, 2012; Harrington and Srai, 2016a). Linking stakeholder 'touch-points' and pre-/post-implementation evaluation criteria can better enable the re-assessment of evaluation quality within the design stage, assess 'performance' implications of alternative service offerings, and critically (and retrospectively) evaluate the adoption of 'smart city' concepts - defined here (BIS, 2013) as those which ..."enable every citizen to engage with all the services on offer, public as well as private...bringing together hard infrastructure, social capital including local skills and community institutions, and (digital) technologies to fuel sustainable economic development and provide an attractive environment for all" - from multiple viewpoints.

\subsection{Design criteria - a multi-stakeholder perspective}

Different approaches to modelling 'last-mile' systems have been reported and reviewed in the literature (Van Duin, 1997; Button and Hensher, 2000; Macharis, De Witte and Ampe, 2009, Crainic, Ricciardi and Storchi, 2009; Muñuzuri, Cortés, Onieva, and Guadix, 2009; Anand, van Duin and Tavasszy 2012; Anand, Yang, van Duin, and Tavasszy, 2012; Greasley and Assi, 2012; Lindholm, 2012; Österle et al, 2015). Design criteria have also been previously utilised, in selected cases, within an urban system context (City Ports 2005; Muñuzuri, Larraneta, Onieva, Cortés, 2005; Van Duin and Quak, 2007; BESTUFS 2007; Russo and Comi, 2011). While practical urban system initiatives have been implemented in several sectors, there is a lack of critical research at the operational design level with respect to common interests and trade-offs (in balancing economic performance at the organisational level, versus the social pressure to improve environmental performance). Furthermore, there is a disconnection - in that service outcomes and benefits cannot be easily estimated by the provider, or validated by the institutional stakeholder.

This section identifies key design criteria - the central research question of this study - derived from supply chain and operations management literature, and applicable to the urban system 'lastmile' - and then categorises from a multi-stakeholder perspective (relevance to consumer, industrial and institutional) - see table 1. Although the authors do not claim this list to be exhaustive, as there has been significant reporting in the academic literature, the synopsis of key literature here demonstrates the tendency of existing research to focus on specific dimensions. Table 1 illustrates the shortcomings in the measurement approaches that are currently employed, as there is a clear bias for an industrial perspective within the criteria, suggesting that decisions may well be largely based on transaction cost considerations. This further highlights the need for a methodology to assess synergies, and trade-offs between multiple agents in terms of performance criteria, and social and service outcomes - representing a novel approach to solution design and evaluation. In taking a stakeholder perspective, and focusing on the design criteria considerations for each actor (e.g. the 3PL company, the retailer, the manufacturer, the local council, the consumer, local transport authority), this approach breaks with traditional city logistics scenario and planning development, replacing a one-size-fits-all mentality, in order to develop more socially-efficient service outcomes. In sections 2.5-2.7 we discuss and propose design criteria for each of the stakeholder groups, in turn. These categories of literature support the case investigation, presented in section 3 , with the output being the development of a theoretical framework.

$\ll$ Insert Table 1 here. Last-mile design criteria from supply chain and operations management literature - multi-stakeholder perspective >> 


\subsection{Consumer design criteria identification}

In the context of parcel delivery, customer evaluation measures should serve to analyse customer requirements and interests. Growing customer expectations have resulted in the need to radically improve services - with requirements for more customised service offerings (Punakivi, Yrjölä and Holmström, 2001; Bhagwat and Sharma, 2007; Gevaers, van de Voorde and Vanelslander, 2010; Angheluta and Costea, 2011). A continued lack of visibility on deliveries remains a significant source of dissatisfaction in this area, with a significant number of consumers deterred from utilising the full potential of internet-based shopping solutions - $41 \%$ of UK customers were recently shown to be dissatisfied with 'tracking, while in transit' aspects of online purchasing (the estimated total number of UK internet users is now close on 72 million) (UPS, 2013)

Service attributes, in terms of the 'customer', have often been categorised using the SERVQUAL framework, which applies the five dimensions of tangibility, reliability, responsiveness, assurance and empathy to define service quality (Parasuraman, Zeithaml and Berry, 1988). Here, five key constructs are proposed to effectively capture the interests and potential objectives of the consumer - cost, quality, time, flexibility and reliability - with respect to offered and received service packages, their attributes and qualities, and correlation to 'last-mile' processes (Lee and Whang, 2001; Lee, Strong, Kahn and Wang, 2002; Boyer and Hult, 2005). Cost, quality and time are viewed as critical in terms of any standard classification (Atkinson, 1999). Ward, McCreery, Ritzman and Sharma (1998) identified flexibility as an additional factor for competitiveness in operations management, which enables a high degree of customer satisfaction. Finally, reliability, is viewed as being highly important for delivery (White, 1996), and may be used to capture post-solution implementation criteria.

Table 2 summarises the relationship of these dimensions/constructs, and design criteria (yaxis) with the key 'last-mile' processes and elements $(x \text {-axis })^{1}$. Within a specific urban system, the consumer is, generally, only concerned with drop point, pick-up distance and destination point (e.g. a customer's home), due to the fact that there may not be any contact with other upstream elements within the 'last-mile'. The importance of service attributes may vary, depending on the requirements of the delivery goods, and customer within a specific urban system. A selection of measures, for drop point, pick-up distance and destination point are presented in table 2. In summary, in terms of the consumer:

- Cost covers performance and utilisation dimensions, with design criteria capturing service price and costs arising from additional services after a purchase, and assets, which the customer has to use, such as the means of transport for a parcel pick-up.

- Quality covers information, material flow and service dimensions - in relation to user satisfaction, intention of use and use (Delone and McLean, 2003; Stevenson and Spring, 2007).

- Time represents processing times, from the customer perspective, and should include criteria such as total lead-time, pick-up time, delivery frequency and hand-over times.

- Flexibility captures customer choice criteria, with respect to cost (pricing models, payment options and range of services), volume, range of services and time. Here, a consumer may choose to customise and use, for example, a "green delivery" option.

- Reliability captures customer choice criteria, with respect to cost, time, place and quality.

\footnotetext{
${ }^{1}$ Note: to illustrate material flows within the urban system 'last-mile', tables 2-4 are organised in order to distinguish between freight transportation and 'stations' within the last-mile value chain. For example, freight transportation includes 'upstream logistics' and 'transportation to drop point' by the logistics service provider and parcel 'pick-up distance' by the customer. 'Stations' within the last-mile value chain include the 'transit-', 'drop-' and 'destination' points. The pick-up distance may be zero, in the case of the destination point being the drop point.
} 
« INSERT Table 2 here. Design criteria from a consumer perspective - in terms of cost, quality, time, flexibility and reliability >>

\subsection{Industrial design criteria identification}

The industrial stakeholder is defined here as the service provider (couriers, express delivery service providers and parcel forwarders), within an urban system. The definition includes activities involving deliveries entering the pre-defined urban area, up to a 'drop point', which is usually predefined by the customer, and the provision of any additional services. The main task, of the industrial stakeholder, is to leverage assets to provide services to satisfy the customer, while adhering to regulations within the urban system (Litman and Burwell, 2006; Green Logistics, 2011).

Current performance measures may not be sufficient for the challenges that organisations will face, with respect to delivering service and environmental outcomes, as they often only detail contractual requirements to define minimum performance levels expected in three performance areas - timeliness, cost and quality/accuracy (Charron, 2006; Jain et al, 2007; Harrington et al, 2012). However, it is argued that industrial stakeholders will have more influence in delivering any future green agenda (Amann, Roehrich, Eßig, and Harland, 2014). Fugate, Mentzer and Stank (2010) also relate logistics performance to three main dimensions, namely, efficiency, effectiveness and differentiation. The dimensions of efficiency and effectiveness look to describe the performance of logistics processes, and can be expressed by quality, cost and time, in terms of measurability (Atkinson, 1999). Finally, in order to adequately reflect critical customer relational attributes in a 'service' business, any measures should be supplemented with appropriate non-financial measurements, and include assessments of the quality of relationships (Harrington et al., 2012).

It is proposed that industrial design criteria utilise the dimensions previously derived for the consumer - cost, quality, time, flexibility and reliability. Table 3 summarises the relationship of these dimensions/constructs and design criteria (y-axis), in terms of the key last-mile processes and elements ( $\mathrm{x}$-axis) - for the industrial stakeholder group. It includes those elements of the urban system 'last-mile', to which the industrial stakeholder has contact, e.g. upstream logistics, the transit point, the transportation to the drop point and the drop point (again, a selection of measures are presented here, as an example). The destination point is also included, in the case that it is the drop point. In summary, in terms of the industrial stakeholder:

- Cost is again sub-divided into utilisation and performance. Objectives here include the reduction of assets and operation costs, while increasing revenue (Yeniyurt, 2003; Leonardi and Baumgartner, 2004; Stathopoulos, Valeri, Marcucci, Gatta, Nuzzolo and Comi, 2011). Utilisation captures all applicable resources, required for service delivery (assets), and performance demonstrates how resources are used (operation costs and revenue).

- Quality consists of information, material flow and service quality. Information and material flows relate to the quality of network connectivity, traffic network integration, labour and transport technology in-use. Service quality may be best represented by customer satisfaction evaluation measures, and may include the development and provision of differentiated services (Swamidass, 2000).

- Time represents process times within the 'last-mile'. Delivery service time is one of the most important evaluation criteria (Bhaqwat and Sharma, 2007). The overarching indicator here is the total lead-time, which summarises the process times along the delivery chain.

- Flexibility - with respect to cost, volume, range and time - may be used to define the capability of the material flow, with levels of flexibility dependent on the quality of information and communication technology in-use. Technological innovations (e.g. RFID, mobile Apps) have the potential to enable higher operational efficiencies and flexibility (Tseng, Yue and Taylor, 2005). By effectively measuring and evaluating this dimension, companies may develop rapid response capabilities to meet individual customer requirements and customised delivery 
services (Gunasekaran, Patel and Tirtiroglu, 2001; Duclos, Vokurka and Lummus, 2003; DHL, 2011).

- Reliability - with respect to the cost, time, place and quality - may be used to assess performance of last-mile logistics solutions, in the implementation phase, as the evaluation criteria may be estimated in the design stage.

$\ll$ INSERT Table 3 here. Design criteria from an industrial perspective - in terms of cost, quality, time, flexibility and reliability >>

\subsection{Institutional design criteria identification}

Institutional interests, within a 'last-mile' context, have been somewhat limited in the literature, despite a critical role in transport infrastructural policies and business development, and in delivering socially responsible operations - as both an active supporter and regulator (Tseng et al., 2005; Amann et al, 2014).

The institutional stakeholder represents the interests of the community, and is comprised of administrative bodies, at a local, regional, national and international level. One of the critical challenges for public organisations, is in the area of performance measurement: to first identify the correct measures to use, and then their effective adoption and management, in light of factors (political, cultural and rational) that may affect the overall process of implementation (Carlucci, Schiuma and Sole, 2015). Hence, the primary task of the institutional stakeholder may be described as to preserve and improve the social and environmental quality of life within their area of responsibility, and ensure that critical environment, social and economic needs are considered in decisions that affect transportation activity (Litman and Burwell, 2006; Muñuzuri et al., 2005).

Social, Technological, Economical, Environmental and Political dimensions are best utilised to specifically capture the objectives of the institutional stakeholder, in balancing revenue generation and quality of living, as part of an evaluation criteria. Table 4 sets out the evaluation criteria and key social, technological, economic, ecological and political measures (y-axis), in terms of the key last-mile processes and elements (x-axis) - for the institutional stakeholders. In the context of this research, many of the indicators focus on operations and, therefore, upstream logistics, transportation and parcel pick-up by the customer. However, the institution is also interested in the end-2-end (E2E) urban system. In summary:

- Social aspects focus on transportation outputs, which may have a direct impact on the quality of life for residents of an urban system. Most challenges are common for the majority of cities (Chapman, 2007; Ott, Sterk and Watanabe, 2008; Copenhagen Accord, UN 2009). Hence, critical factors, such as level of congestion, and number of road accidents, caused by the number of operating vehicles, are captured within this dimension.

- A key consideration, in assessing solutions, is the role emerging technology may play in the development of alternative services (Harrington and Srai, 2016b). In terms of the technology dimension, critical factors reducing the negative impacts of the overall operating system should be captured. In relation to hardware, the promotion of high tech facilities and lowemission vehicles is of great interest to the institutional stakeholder, as are up-to-date routing software/intelligent transportation systems (ITS) to improve efficiency, and reduce operational costs.

- The environmental dimension aims to capture the negative impact of transportation. Studies reflecting the high contribution of freight transportation, within defined urban systems, have already been reported, with subsequent implementation of policies and outcomes, in relation to expected goals (Patier, 2002; OECD, 2003; Figliozzi, 2007; Comi, Delle Site, Filippi, Marcucci and Nuzzolo, 2008; Sonntag and Meimbresse, 2008; Stathopoulos et al, 2011). 
- Economical aspects are represented by costs for the community, caused through freight transportation. Cost reduction here is of common interest for both the institutional and industrial stakeholder. Solutions and strategies, which promote reductions in freight volume, travel time, interferences, and increase revenue and speed, improve not only community costs but also the performance of the 'last-mile' solution provider.

- A political dimension may be used to capture responsible, and cooperative behaviour, between the industrial and institutional. Stakeholders should not only conform to regulations, but also challenge these norms, in order to improve the quality of life for the wider community (Frota Neto, Bloemhof-Ruwaard, van Nunen and van Heck, 2008).

$\ll$ INSERT Table 4 here. Design criteria from an institutional perspective - social, technological, environmental, economical and political >>

\section{Methodology}

A case study methodology (Eisenhardt, 1989; Yin, 2009; Voss, 2009) was used to address the core research question of this study - determining those key design criteria, from a multi-stakeholder perspective, that are applicable to urban system 'last-mile' operations - and guided by the framework, derived from the literature, in section 2. Key criteria for case selection included (i) access to, and involvement in, concept building and the early stages of implementation of an innovative logistics solution, within a pre-defined urban system and (ii) an ability to both capture perspectives of a series of key stakeholder groups, within a collaborative supply network (for example, final customers, the parcel delivery organisation and the local authority), to allow full exploration of the design criteria, characteristics and constructs.

The in-depth case study, supported by the UK Technology Strategy Board, involved the implementation of a Consumer Choice Portal and Package Consolidation Centre (CCP-PCC), focused on the delivery of packages to the home. This 'last-mile' solution design involved a web-based portal, offering consumer choice features such as time, mode of delivery (e.g. sustainable vehicle solutions, self pick-up) and parcel traceability, coupled with a local urban consolidation centre providing easy consumer access, consolidation facilities for primary suppliers, efficient transfer to last-mile couriers with dynamic scheduling, and package recycling features. The geographical area, selected for this study, was in the greater London area, operating within two specific postcodes, and delivering to a potential customer base of approximately 50,000 households - reflecting a potential market size of $\sim 250 \mathrm{k}$ packages. With the assumption that up to $30 \%$ of deliveries may be missed first time (Fernie and McKinnon, 2004), this would translate to 600 parcels/day, out of the 2,000 delivered daily, in the specified geographical area.

The overall investigative approach (data collection, analysis and integration with the literature and underpinning concepts) involved:

- Step 1. 'Operationalising' the multi-stakeholder design criteria, through the in-depth case study, as a means of developing a conceptual framework. Data collection activities involving the focal firm (PCC operating company) and all network collaborators were undertaken by one, or a combination of the authors, over a two year period (from summer 2010 to the end of 2012), and involved the concept, design and implementation phases of the CCP-PCC 'lastmile' solution. A four-tiered approach was used as part of this step, i.e.

(1) Interviewees (see table 5 for summary and descriptions) first discussed their general view on the PCC-CCP operation, and involved: 
- A cross-section of PCC-CCP early adopter/customers, selected to explore how the specific solution may change/affect their business and daily life, and result in the development of future PCC-CCP services

- Industrial stakeholders consisting of (i) the PCC operating company, a small business operating from regional bases across the UK, with primary offices located in greater London and established for more than fifteen years, and (ii) the Green Business Forum (GBF), a partnership between local businesses and the local authority.

- The local authority (LA) responsible for the geographical area in which the PCC operated. The LA mission states a dedication 'to improving the lives of our residents' and an ambition 'to deliver the best quality of life in Britain' by 'providing high-quality, targeted services that deliver real value for money'. As an active supporter of the case study, several respondents (with responsibilities in planning environment, technical standards, infrastructure delivery, highways, traffic division and procurement framework design/supplier pre-qualification) represented the interests of the 'institutional' stakeholder

(2) Interviewees described their perceptions of the identified dimensions, in the context of the PCC project - social, technological, economical, environmental, political, cost, quality, time, flexibility and reliability. This enabled a direct determination of potential criteria spanning stakeholder interests. Pre-/post-implementation requirements, and usage patterns, were then used to identify potential process/performance measures for each of the stakeholders, and the overall industrial system. Evaluation metric definitions, involving efficiency, service and sustainability parameters, were discussed at critical points within these two echelon ('last-mile' and pre-'last-mile') supply chains.

(3) Interviewees were asked directly for evaluation criteria, which may not have been addressed, as part of the interview.

(4) The last section of the interview process served to identify the most important measures, for each interviewee and additional information, which had not been captured.

- Step 2. Multi-organisational service network (MOSN) concepts and supply chain mapping techniques (Srai and Gregory, 2008) were used to identify common interests and trade-offs, involving the relevant stakeholder groups (consumers, industrial and institutional) in terms of socio-environmental, efficiency and service benefits. Specifically, process mapping of the decision-making processes of institutional and industrial actors was undertaken, to identify any regulatory barriers/opportunities to/for the successful adoption of smart city-enabled operational applications/alternative delivery systems.

The data collection process involved multiple site visits over this two-year period, a series of semi-structured interviews and informal meetings with PCC customers, company representatives, including the managing director and operations director of the PCC, CCP technology developers, and officers of the LA. In addition, secondary data and company materials were used, which included annual reports, press releases, presentation material to customers and stakeholders, media material, and other secondary literature sources. Furthermore, follow up e-mail correspondence, and data validation by the key stakeholder groups was conducted, in order to increase the validity and reliability of the study

- Step 3. A conceptual framework was developed through application of multi-stakeholder design criteria, as part of the in-depth case study implementation phase (outputs from steps 1 and 2 above), and triangulation of multiple sources. This informed evaluation of the specific CCP-PCC solution. It is the aim that successful solution implementation will act as a prototype 
demonstrator, in a specific geographical location, in order to examine viability and develop standards and protocols to enable licensed/accredited logistics distributors to use the system.

$<<$ INSERT Table 5 here. Case study interviewees and descriptions >>

\section{Case study results and development of conceptual framework categories}

This section is organised to align with the private-public institutional themes consulted in the literature review (section 2), with the view to linking synthesis of theory, with the data (case study). As a means of developing a theoretical design framework, the criteria identified from a critical synthesis of the literature was 'operationalised', by applying these concepts to the three key stakeholder groups. The in-depth case study was specifically chosen, as it demonstrates innovations in consumer choice, institutional policy practice and industrial delivery options. Semi-structured interviews, with the target stakeholder groups, were then used to explore the interfaces between stakeholders.

The findings reflect the implementation of a newly established Consumer Choice Portal (CCP) and Package Consolidation Centre (PCC) solution within a specific densely populated urban geography (see section 4.1). The interview outputs 'populate' a conceptual framework, by identifying the design considerations important to the three stakeholder groups, identifying in the process the potential synergies (overlaps) where a more collaborative approach to 'smarter' network, and solution design may lead to collective socio-environmental, efficiency and service benefits.

Figure 1 and Table 6, collectively, represent the outputs - in terms of a conceptual framework for evaluating a specific urban system 'last-mile' solution, across the three key stakeholder groups. Individual design criteria, for each stakeholder group, are outlined in sections 4.2 - 4.4. Figure 1 also summarises the key interaction/integration points - identified from mapping and interviews, involving the stakeholder groups - to capture critical interdependencies, common interests and trade-offs. It is in these overlap spaces (dyadic and triadic design criteria - sections $4.4-4.8$ ), where the primary contribution of this research has been focused.

$\ll$ INSERT Figure 1 here. Emerging multi-stakeholder conceptual framework - capturing key design considerations incl. interdependencies, common interests and trade-offs >>

\subsection{Implementation of an urban system 'Iast-mile' solution}

The conceptual framework developed (figure 1) informed the process of implementing a specific urban system 'last-mile' solution, involving package delivery to the home. Solution design consisted of a web-based portal providing consumer choice features, such as time and mode of delivery, the development and implementation of new routing system software, 'green' delivery options, that included the use of small electric vehicles, and the set-up of a parcel consolidation centre. The overall project aim was to empower consumers, with respect to their delivery option, in the 'last-mile' of the package journey.

Assessing the past phases of a development is crucial to avoid, or correct erroneous trends, in an urban project or city (Manville, Cochrane, Cave, Millard, Pederson, Thaarup, Liebe, Wissner, Massink and Kotterink, 2014). Any evaluation should assess whether the objectives of projects have been accomplished, be of a continuous and independent nature operationally (with the option of 
evaluating at discrete points in time), and have a precondition that there are clear, measurable objectives (ibid). This unique approach - encompassing social and economic perspectives of all stakeholder groups, within a specific urban system - led to the development of a common set of measures in order to estimate performance in a design stage and to measure 'actual' performance in post-implementation stages. Table 6 illustrates an example of the measures identified and their 'operationalisation', in terms of the current state of implementation of the 'last-mile' solution and targeted service outcomes (specific design criteria, selected for the solution on the y-axis v. service outcome options on the $x$-axis). The table highlights (i) current levels of service outcome (ii) the current stage of 'last-mile' solution implementation, and (iii) targeted (and demonstrated) 'last-mile' solution outcomes.

Customers are informed about the arrival of the delivery good, and the portal enables greater choice involving two delivery modes; self pick-up, or delivery by electric vehicle, within a specific and narrow time window. The solution mainly promotes customer connectivity - hence, evaluation of the information quality between customer and CCP-PCC should include completeness, ease of understanding, personalisation, relevance and security. As well as communication via e-mail and SMS, the CCP provides an ability to engage, interact, integrate and communicate in real time, as and when appropriate with customers, improving delivery efficiency and overall service features.

Alternative delivery modes, additional service features, such as the selection of delivery time with a time window of only one hour and the possibility of changing the destination point, further serve to increase customer choice. Longer opening times, 7 days per week provide greater time flexibility for the customer, in terms of home delivery or collection. The additional option of using the consolidation centre for parcel storage of up to one week enables aggregation of parcels and, therefore, not only benefits the customer but also promotes a highly efficient 'last-mile' logistics delivery for industrial and institutional stakeholders. The delivery option, by electric vehicle, minimises the generation of emissions, and is of value to all stakeholders.

Actively promoting a local transit point - with accessibility for all shippers - highlights the critical role institutional players could play in facilitating/supporting the design and implementation of novel solutions, as part of a more-partnered approach. In future stages of the project, the involvement of other delivery service providers, who may be willing to cover this cost (fully or partly) through the elimination of their individual last-mile logistics costs, could further increase the performance and attractiveness of the last-mile urban system solution.

$\ll$ INSERT Table 6 here. Design criteria and service outcomes for the CCP-PCC 'last-mile' solution

\subsection{Developing consumer design criteria}

Within any specific urban system, the consumer is, generally, only concerned with drop point, pick-up distance and destination point. All customer groups stressed the importance of a requirement for 'high convenience', which includes reliability and flexibility, customer choice in changing the delivery time and destination, longer operating and opening times, the option of parcel aggregation, and dependable deliveries in narrow time windows. Critically, one respondent stated that service providers should be 'clear in what they can achieve', in terms of reliability.

The three customer groups interviewed evaluated the performance of two PCC service modes (pick-up and delivery), with communication channels via SMS and e-mail. The personal and friendly contact initiated between customer and a local service provider brought added familiarity and a high customer satisfaction rating, building a relationship through having a 'personal touch' and a 'safe environment'. The key critical point was service price (trade-off between consumer and service 
provider), whilst general negatives arising from the customer interviews were the (current) limitation, with respect to the weight of delivery goods $(<25 \mathrm{~kg})$, and the lack of an insurance option for high value deliveries. However, customer interviewees were willing to pay a service price, for the pick-up option, as it impacted positively on personal time management - one customer describing the saved time as being 'invaluable', as it enabled him to 'spend more time with family...' and removed a reliance on neighbours' accepting SME-related deliveries when not at home (the inconvenience of having to 'bother the neighbours'). Others recognised environmental benefits through the electric vehicle delivery option, stating that the delivery option was a 'unique selling point', which initially attracted attention to the PCC service, with one consumer stating "...if there wasn't an electric vehicle delivery option, I wouldn't use the service". High performance of time flexibility and price sensibility were not seen as critical factors in this case.

\subsection{Developing industrial design criteria}

In terms of the industrial stakeholder interviewees, discussions largely centred on social aspects (in terms of infrastructure improvement, and reduction of community costs) and industrial efficiency dimensions, focused on customer service outcomes and financial profit (which will only be achieved with scale). Key interests of industry included creating 'new revenue streams', 'increasing in-house skills' and 'increasing own brand reputation'. Hence, main evaluation criteria should include measures capturing innovation and new service development, e.g. the exploration of new business models and 'opportunities for franchising'. It was noted that the key performance indicator of on-time delivery 'first time' (with no damaged delivery good) achieved rates approaching $100 \%$, during a peak 3-month timeframe (at the time of the interviews).

Interests of the Green Business Forum (GBF) interviewees focused largely on the promotion of green and local business, with outputs from the interviews illustrating more of a strong correlation with institutional interests. Increasing customer satisfaction directly was, however, not viewed as important as economic development. Main interest with respect to evaluation measures included number of users, the growth of turnover, the growth of employees, revenue and margin.

\subsection{Developing institutional design criteria}

The process here involved a wide range of institutional stakeholders, with specific roles and responsibilities within the local authority. Multi-organisational network (MON) concepts, and supply chain mapping techniques led discussions on the identification of opportunities, constraints, common interests and trade-offs, across the relevant institutional stakeholder groups, for the specific last-mile solution. In addition, mapping of the decision-making processes of institutional actors to identify any regulatory barriers/opportunities for successful adoption was conducted. Specific process and performance/compliance requirements were explored, in terms of current and future institutional obligations, for the individual institutional stakeholders and included: increased cross-functional standardisation, enhanced communication streams, enabling a shift from 'commissioning' to 'contracting' and 'advisory' to 'strategic', driving public-private M\&A/JVs, set-up of local authority trading companies, 'services' selling, addressing an 'over-specification' of performance indicators, development of an integrated model for re-tendering of contracts and improved contract management and performance measurement.

Overall, interests of the institutional (LA) interviewees remain strongly linked to political targets which include (i) the reduction and elimination of the negative side-effects of parcel transportation and delivery, in terms of pollutants and maintenance costs, (ii) increasing the attractiveness of the urban area for residents - in institutional terms, the maximisation of 'customer' satisfaction, (iii) facilitating technology transfer and innovation, relating to economic development, especially in terms of local businesses and (iv) to be seen to lead engagement activities between government, industry, and academia. In summary, interests focus on improving the 'reputation' of the institutional stakeholder.

\subsection{Developing consumer - industrial criteria}


Costs are the pre-dominant criterion, with the price for service use a trade off between customer and service provider. Financial indicators, such as service price (including after delivery services, and service changes after purchase), communication costs, or the compensation for low service performances were identified as central to the common interest areas of consumers and industry.

\subsection{Developing consumer - institutional criteria}

Despite direct contact between customer and institution being minimal, indirect influence can not be underestimated, in the context of the 'last-mile' - with the institution representing the interests of the community, and the individual customer highly affected by the community he/she is living in. Direct contact relates to pick-up distance for the customer. Depending on the distance to the pick-up point, the type of the delivery good and the available means of transport, the customer may chose the option to collect the parcel. This may generate, not only high extra costs for the customer, but also exasberates issues that the institutional stakeholder seeks to prevent. Therefore, in this case both may be interested in an additional closed collection point service option, as part of a solution redesign.

\subsection{Developing industrial - institutional criteria}

Ten key criteria emerge in this space, namely, market growth, the number of operating vehicles, vehicle $\mathrm{km} /$ parcel, load factor, level of traffic network integration, driver experience, load/unload times, transport time, consumption rates and energy pricing (tax). Factors such as, the occupancy of the consolidation centre, the average vehicle kilometres per parcel, the load factor, the number of operating vehicles and the average transport time per parcel have the potential for conflict, due to the fact that the industrial stakeholder attempts to satisfy the customer, accepting lower delivery performance. The express delivery option, for example, bypasses the transit point with the aim to reduce the total lead-time for the customer, who usually pays a higher price for this special service feature. Attention must be paid to the average transport time per parcel, which emerges as a common indicator for all three stakeholders. However, the higher performance of this indicator could have implications on a longer consolidation time with the result being longer lead-times for the customer, which is the only time he/she is interested in. This scenario illustrates the potential of the dynamic framework, which may avoid such equivocations, through simple and clear indicator re-allocation. Driver skills (experience), traffic network integration, or consumption rate are quality factors of 'lastmile' logistics and, therefore, representative of the efficiency, which is performance driver for the costs as well as for the environment.

\subsection{Developing consumer - industrial - institutional criteria}

Despite the three stakeholder groups having many different interests in a last-mile urban system context, some common indicators have been be identified as part of the 'last-mile' solution e.g. customer satisfaction (for example, number of attempted deliveries), customer complaints (in terms of cost, quality, time, flexibility and reliability), range of services (i.e. 'green' choice service options), range of services (after-purchase options), deliveries on time (OTIF, \% deliveries on destination route), total damaged and lost parcels, handover and lead-times, delivery time window and frequency. All participants want a delivery system with high quality. The range of services, representing the customer's satisfaction before purchasing, supports market growth or economic development, which is important to the industry, as well as to the institution. Customer satisfaction after purchasing is represented by the dimension reliability, which includes indicators such as lead-time deviation (or delivery reliability), deliveries on time, damaged or lost parcels and customer complaints. These factors are usually common interests, due to the fact that their low performance causes additional cost for the delivery service and high dissatisfaction for the customer. A trade-off is the delivery frequency, because a high frequency disagrees usually with the delivery efficiency, such as parcel kilometres or 
efficiency of vehicle use. High customer connectivity avoids unnecessary operations through, for example, a quick reaction to order changes. Lead-time, handover time, delivery tries and delivery time window are correlated to the efficiency of the delivery process. The delivery time window is a trade-off between the customer and the other two stakeholders.

\section{Conclusion and directions for further research}

This study presents an approach to designing and evaluating 'last-mile' solutions, capturing the social and economic interests, trade-offs and perspectives of key stakeholders within a specified urban system. In terms of supply chain modelling and optimisation, much attention has been focused on the development of chains and networks, often neglecting the first and last section of the chain. While initiatives have already being implemented, there remains a lack of critical research at the operational level, with no general approach to evaluating critical service outcomes and benefits (that cannot be easily estimated by the provider, or validated by the institutional stakeholder). It is proposed, that for such initiatives to be most effective, they will require more targeted evaluation measures to be identified for individual stakeholder groups. Coming from an operations management perspective, this research may better inform the critical evaluation of impact with respect to smart city policies on operations management; in particular the adoption of smart city concepts, the identification of opportunities and constraints with respect to all stakeholders.

A conceptual framework is developed that captures the key design factors to be considered by industrial, institutional and consumer groups in the configuration of a 'last-mile' solution, with insights on those design criteria and performance attributes that have a multi-stakeholder input. This subset, of design factors and performance attributes, may enable more innovative solutions to address multiple stakeholder objectives, targeting synergies and trade-offs for system-wide benefits. By empowering consumers, with respect to 'last-mile' delivery options, the approach looks to break with traditional city logistics development, by bringing more of an element of consumer participation and social input, in order to develop more socially-efficient service outcomes - replacing a one-size-fits-all paradigm.

The approach is based on a set of design criteria, derived from supply chain and operations management literature, and from examples of existing urban system solution implementations. The design criteria identified were then categorised, from a multi-stakeholder perspective, and then 'operationalised' through an in-depth case study involving the design and implementation of a newly established Consumer Choice Portal (CCP) and Package Consolidation Centre (PCC), within a specific urban geography, as a means of developing a conceptual framework, by the triangulation of multiple sources. Supporting analyses, based on supply chain mapping and multi-organisational network concepts, further informed identification of a common and focused set of measures (from hundreds of potential measures) that integrate the critical stakeholder groups, within an urban system 'last-mile', and identify synergies to promote a more collaborative approach to 'smarter' network and solution design. Key findings from the case study have demonstrated the critical role of institutional players in supply chain innovation, suggesting new policy approaches are required to facilitate/support the design and implementation of novel solutions, as part of a more-partnered (as opposed to regulatory control) approach. This, in turn, may enable the development and implementation of simple and workable solutions in urban environments, which focus more on a collaborative approach between institutional, industrial and end-customers. Outcomes from our interviews suggested that hybrids of the three predefined stakeholder types exist, where there are common interests and trade-offs. Hence, a comprehensive evaluation approach should include dimensions, for capturing all critical 'touch points' and associated evaluation criteria, for each stakeholder.

Although practical smart city advancements are already being implemented in several sectors, there is a lack of critical research on operations. This paper aims to close this gap by analysing the connections between smart cities and operations management. In terms of theoretical contribution, this research offers a valid contribution to the literature in the operations domain, especially in the area of institutional stakeholder engagement. It is proposed that the role of institutional players, in the governance of urban system 'last-mile' solution evaluation, design and implementation be re-defined, or extended in order to support more outcome-oriented systems (with greater alignment on customer 
and industrial stakeholder interests). The conceptual framework development advances operations theory in the area of service outcome-based performance measures at the industrial system level as no construct currently exists which shows the relationship between the different measures and, therefore, between the interests of the different stakeholders (institutional, industrial and customer). In terms of practical contribution, many city-enabled operational initiatives fail to proceed to the implementation phase because benefits may not be effectively (or correctly) evaluated easily. The 'last-mile' logistics design approach involving social and institutional criteria - introduced in this paper has business and economic implications for managers active in urban logistics and operations, and is equally applicable in areas such of manufacturing, retailing, freight management and transportation. Outputs from implementation of the framework can provide valuable supporting evidence for city planners, supply chain designers, and B2C service providers to better understand alternative solutions, within an urban environment (by using a multi-stakeholder/network perspective). It enables stakeholders to evaluate performance implications of alternative service offerings, and to critically evaluate the adoption of 'smart city' concepts. It is also set-up to enable differentiation between pre/post-implementation criteria to enable evaluation and re-evaluation in both stages - linking performance of the solution in the design stage, with real performance in the post-implementation stage of the project. The richness of assessed data lies in enabling a correlation of both stages and, therefore, the improvement of evaluation quality in the design and re-design stage. Strategically and operationally - in terms of institutional impact - the approach may also enable the introduction of social institutions into city operations planning, through the promotion of hybrid public-private entities.

Finally, suggested directions for future research in this area centre on mechanisms for scaleup/out and the exploration of partnership types with other supply chain actors (i) downstream with public sector bodies and (ii) upstream with 'competing' couriers. In addition to extending the research to a B2B context, future case studies will look to test the model in other urban systems (both nationally and internationally) and identify the hard and soft factors that influence public sector approval, and inform collaboration models, between private companies and public resources. Focus will look to link the key processes and requirements of stakeholders, to inform the potential development of new industry standards.

\section{References}

Aized, T., Srai, J.S. (2013) "Hierarchical modelling of last-mile logistics distribution system", International Journal of Advanced Manufacturing Technology, Vol. 70 No. 5-8, pp. 1053-106. DOI 10.1007/s00170-013-5349

Amann, M., Roehrich, J.K., Eßig, M., Harland, C. (2014) "Driving sustainable supply chain management in the public sector: The importance of public procurement in the European Union", Supply Chain Management: An International Journal, Vol. 19 Iss: 3, pp.351-366. DOI: 10.1108/SCM12-2013-0447

Angheluta, A. and Costea, C. (2011), "Sustainable go-green logistics solutions for Istanbul Metropolis", Transport Problems, Vol. 6 No. 2, pp.59-70.

http://transportproblems.polsl.pl/pl/Archiwum/2011/zeszyt2/2011t6z2_08.pdf

Anand, N., Quak, H., Van Duin, J.H.R., Tavasszy, L. (2012) "City Logistics Modelling Efforts: Trends and Gaps-A Review", Procedia Social and Behavioural Science, 39, 101-115. DOI: 10.1016/j.sbspro.2012.03.094

Anand, N., Yang, M., Van Duin, J. H. R., Tavasszy, L. (2012) "GenCLOn: An ontology for city logistics", Expert Systems with Applications, 13 (15), pp. 11944-11960.

DOI: 10.1016/j.eswa.2012.03.068

Atkinson, R. (1999), "Project management: cost, time and quality, two best guesses and a phenomenon, its time to accept other success criteria", International Journal of Project Management, 
Vol. 17 No. 6, pp. 337-342. DOI: 10.1016/S0263-7863 (98) 00069-6

BESTUFS/Allen, J. T., Browne, M. (2007) Good Practice Guide on Urban Freight Transport. Available at: http://www.bestufs.net/download/BESTUFS_II/good_practice/English_BESTUFS_Guide.pdf>

Bhagwat, R. and Sharma, M. (2007), "Performance measurement of supply chain management: A balanced scorecard approach”, Computers \& Industrial Engineering, Vol. 53 No. 1, pp. 43-62. DOI: 10.1016/j.cie.2007.04.001

BIS (2013) "Smart Cities", Available at:

https://www.gov.uk/government/uploads/system/uploads/attachment data/file/246019/bis-13-1209smart-cities-background-paper-digital.pdf (accessed 01.12.2015)

Björklund, M., Martinsen, U., Abrahamsson, M (2012) "Performance measurements in the greening of supply chains", Supply Chain Management: An International Journal, Vol. 17 Iss: 1, pp.29-39. DOI: $10.1108 / 13598541211212186$

Boyer, K., Frohlich, M.T., Hult, G. (2004) "Extending the supply chain: how cutting-edge companies bridge the critical last-mile into customers' homes". 1st edition. New York / USA: AMACOM / American Management Association 2004. ISBN: 978-0814408360.

Boyer, K., Hult, G. (2005) "Extending the supply chain: integrating operations and marketing in the online grocery industry", Journal of Operations Management, Vol. 23 No.6, pp. 642-661.

DOI: 10.1016/j.jom.2005.01.003

Boyer, K., Prud'homme, A. and Chung, W. (2009), "The last-mile challenge: evaluating the effects of customer density and delivery window patterns", Journal of Business Logistics, Vol. 30 No. 1, pp. 185201. DOI: $10.1002 / j .2158-1592.2009 . t b 00104 . x$

Browne, M., Sweet, M., Woodburn, A., Allen, J. (2005), Urban freight consolidation centres final report, Transport Studies Group, University of Westminster. Available at: http://ukerc.rl.ac.uk/pdf/RR3_Urban_Freight_Consolidation_Centre_Report.pdf

Button, K.J., and Hensher, D.A. (2000), Handbook of transport modeling, edited by David A. Hensher, Kenneth J. Button, Elsevier Science B.V., New York

Caplice. C., Phadnis, S (2014) "A Better Approach to Infrastructure Planning", Harvard Business Review, July. Accessed on-line (22.07.15) at: https://hbr.org/2014/07/to-see-eye-to-eye-oninfrastructure-use-scenario-planning/

Carlucci, D., Schiuma, G., Sole, F (2015) "The adoption and implementation of performance measurement process in Italian public organisations: the influence of political, cultural and rational factors" Production Planning \& Control Vol. 26, Iss. 5, pp .363-376. DOI: $10.1080 / 09537287.2014 .906678$

Charron, K.G. (2006) "Why KPIs belong in supply chain contracts", Supply chain management review, Vol. 10, No. 2, pp. 22-28

Chapman, L. (2007) “Transport and climate change: a review", Journal of transport geography, Vol.15 No. 5, pp. 354-367. DOI: 10.1016/j.jtrangeo.2006.11.008

Chopra, S. (2003) "Designing the distribution network in a supply chain", Transportation Research Part E: Logistics and Transportation Review, Vol. 39, No. 2, pp. 123-140. DOI:10.1016/S13665545(02)00044-3

City Ports/Panebianco, M. Zanarini, M. (2005) CITY PORTS PROJECT: Interim Report 2005. Available at: http://mobilita.regione.emilia-romagna.it/entra-in-regione/Pubblicazioni/i-quaderni-delservizio-pianificazione-dei-trasporti-e-logistica/quaderno 7.pdf

Comi, A., Delle Site, P., Filippi, F., Marcucci, E., Nuzzolo, A. (2008) “Differentiated regulation of urban 
freight traffic: conceptual framework and examples from Italy". (Ed.): Proceedings of 13th International Conference of Hong Kong Society for Transportation Studies, Hong Kong

Crainic T.G., Ricciardi, N., Storchi, G. (2009) "Models for Evaluating and Planning City Logistics Systems”, Journal Transportation Science, Vol. 43 Issue 4, pp. 432-454. DOI: 10.1287/trsc.1090.0279

Danielis, R., Maggi, E., Rotaris, L., Valeri, E. (2012) 'Urban supply chains and transportation policies' SIET Working paper, available at: http://www.sietitalia.org/wpsiet/Rotaris\%202012 1.pdf (accessed 21.10.2015)

Davis, F.W., Manrodt, K.B. (1994) 'Service Logistics: An Introduction', International Journal of Physical Distribution \& Logistics Management, Vol. 24 Iss: 4, pp.59 - 68. DOI

http://dx.doi.org/10.1108/09600039410757658

Delone, W. and McLean, E. (2003), "The DeLone and McLean model of information systems success: A ten-year update", Journal of Management Information Systems, Vol. 19 No. 4, pp. 9-30.

DOI:10.1080/07421222.2003.11045748

DfT (2015), "Quiet deliveries: good practice, principles and processes", Available at:

https://www.gov.uk/government/publications/quiet-deliveries-demonstration-scheme (accessed 26.11.2015)

Duclos, L., Vokurka, R. and Lummus, R. (2003), "A conceptual model of supply chain flexibility", Industrial Management \& Data Systems, Vol. 103 No. 6, pp. 446-456. DOI:

$10.1108 / 02635570310480015$

DHL (2011) “The first and last-miles”, Available at: http://www.dhl

discoverlogistics.com/cms/en/course/technologies/reinforcement/first.jsp?pdf=1 (accessed 05.06.2015)

Eisenhardt, K.M. (1989) "Building Theories from Case Study Research", Academy of Management Review, Vol. 14, No. 4, pp. 532-550.

Esper, T.L., Jensen, T., Burton, S. and Turnipseed, F. (2003), "The Last-mile: An Examination of Effects of Online Retail Delivery Strategies on Consumers," Journal of Business Logistics, Vol. 24 No. 2, pp. 177-203. DOI: 10.1002/j.2158-1592.2003.tb00051.x

Fernie, J., McKinnon, A.C. (2004), The development of e-tail logistics, in, Logistics and Retail Management, 2nd ed., Kogan Page, London.

Figliozzi, M. (2007) "Analysis of the efficiency of urban commercial vehicle tours: Data collection, methodology, and policy implications", Transportation Research Part B: Methodological, Vol. 41 No. 9, pp. 1014-1032. DOI: 10.1016/j.trb.2007.04.006

Foss, B., Stone, M., and Ekinci, Y. (2008), "What makes for CRM system success - or failure?", Database Marketing \& Customer Strategy Management, Vol. 15 No.2, pp. 68-78. DOI:

$10.1057 / \mathrm{dbm} .2008 .5$

Frota Neto, J., Bloemhof-Ruwaard, J., van Nunen, J. and van Heck, E. (2008) "Designing and evaluating sustainable logistics networks", International Journal of Production Economics, Vol. 111 No. 2, pp. 195-208. DOI: 10.1016/j.ijpe.2006.10.014

FT (2013), "Royal Mail float set to heighten postal competition“, Available at: http://www.ft.com/cms/s/0/d435db1c-f7d1-11e2-87ec-00144feabdc0.html\#axzz3hpdHCBZ5

Fugate, B., Mentzer, J. and Stank, T. (2010), "Logistics Performance: Efficiency, Effectiveness, and Differentiation”, Journal of Business Logistics, Vol. 31 No. 1, pp. 43-62. DOI: 10.1002/j.21581592.2010.tb00127.x

Gately, C.K., Hutyra, L.R., Wing, I.S. (2015), "Cities, traffic, and CO2: A multi-decadal assessment of 
trends, drivers, and scaling relationships", PNAS, Vol. 112 No. 16, pp. 4999-5004. Available at: http://www.pnas.org/content/112/16/4999.full.pdf (accessed 26.11.2015).

Gevaers, R., van de Voorde, E. and Vanelslander, T. (2010), "Characteristics and Typology of Lastmile Logistics from an Innovation Perspective in an Urban Context, Proceedings of the 12th WCTR, Lisbon, Portugal, pp. 11-15

Gimenez, C., Tachizawa, E.M. (2012), "Extending sustainability to suppliers: a systematic literature review", Supply Chain Management: An International Journal, Vol. 17 No. 5, pp. 531-543. DOI: $10.1108 / 13598541211258591$

Graham, G., Coles, E., Mehmood, R., (2015) "Exploring Future Cityscapes through Urban Logistics Prototyping: a Technical Viewpoint”, Supply Chain Management: an International Journal, 20(3), pp. 341-352. DOI: 10.1108/SCM-05-2014-0169

Green Logistics (2011), “What is Green Logistics?”, Available at: http://www.greenlogistics.org/index.htm

Greasley, A., Assi, A. (2012) "Improving "last-mile" delivery performance to retailers in hub and spoke distribution systems", Journal of Manufacturing Technology Management, Vol. 23 Issue 6, pp. 794805. DOI: $10.1108 / 17410381211253344$

Gunasekaran, A., Patel, C. and Tirtiroglu, E. (2001), "Performance measures and measures in a supply chain environment", International Journal of Operations and Production Management, Vol. 21 No. 1-2 pp. 71-87. DOI: 10.1108/01443570110358468

Harrington, T.S., Kirkwood, D.A. and Srai, J.S. (2012), "Performance Metric Selection Methodology for Multi-Organizational Service Network Design", Journal of Applied Management and Entrepreneurship, Vol. 17 No.3, pp. 20-35.

Harrington, T.S., Srai, J.S. (2012) 'Defining product-service network configurations and location roles: a current and future state analysis framework for international engineering operations', International Journal of Product Development, Vol. 17, Nos. 3/4, pp. 228-253. DOI: 10.1504/IJPD.2012.052103

Harrington, T.S., Wohlrab, J., Srai, J.S. (2012) 'Last-mile logistics evaluation - customer, industrial and institutional perspectives', $23^{\text {rd }}$ Annual Production and Operations Management Society (POMS) conference proceedings. Chicago IL, April 27-30th

Harrington, T.S., Srai, J.S., Christodoulou, P. (2014) 'Developing service supply networks', in, 'Capturing value from global networks: strategic approaches to designing international production, supply and service operations', University of Cambridge, Institute for Manufacturing, pp. 30-37. ISBN: 978-1-902546-30-8

Harrington, T.S., Srai, J.S. (2016a, forthcoming) 'Designing a concept of operations architecture for next generation multi-organisational service networks', Al and Society: J. Knowledge, Culture and Communication (in print)

Harrington, T.S., Srai, J.S. (2016b, forthcoming) 'Understanding stages of supply network emergence in technology commercialisation', International Journal of Manufacturing Technology and Management (in print)

Hervani, A.A., Helms, M.M., Sarkis, J. (2005), "Performance measurement for green supply chain management", Benchmarking: An International Journal, 12(4), pp. 330-353. DOI:

10.1108/14635770510609015

Ho, J.K. (1997) "What can contemporary systems thinking offer to logistics management as a management discipline", European Journal of Purchasing \& Supply Management, Vol. 3 No. 2, pp. 77 81. DOI: 10.1016/S0969-7012(97)00003-8

Jain, R., Jain, S., Dhar, U. (2007), “CUREL: A Scale for Measuring Customer Relationship 
Management Effectiveness in Service Sector", Journal of Services Research, Vol. 7 No. 1, pp. 37-58.

Kumar Dey, P., Cheffi, W. (2013) "Green supply chain performance measurement using the analytical hierarchy process: a comparative analysis of manufacturing organizations", Production Planning and Control, 24/8-9, pp. 702-720. DOI: 10.1080/09537287.2012.666859

Kumar M. and Gregory M. (2013), "An exploration of Risk Management in Global Industrial Investment, Risk Management", Risk Management Journal, Issue 15, Vol 4, pp 271-300. DOI: 10.1057/rm.2013.8

Lee, H.L., Whang, S (2001) "Winning the Last-mile of E-Commerce". MIT Sloan Management Review, July. Accessed on-line (22.07.15) at: http://sloanreview.mit.edu/article/winning-the-last-mile-ofecommerce/

LaMiLo (2015) Available at: http://www.lamiloproject.eu (accessed 01.12.2015)

Lee, Y., Strong, D., Kahn, B., Wang, R. (2002) "AIMQ: a methodology for information quality assessment", Information \& Management, Vol. 40 No. 2, pp.133-146. DOI: 10.1016/S03787206(02)00043-5

Leonardi, J. and Baumgartner, M. (2004), " $\mathrm{CO}_{2}$ efficiency in road freight transportation: Status quo, measures and potential", Transportation Research Part D: Transport and Environment, Vol. 9 No. 6, pp. 451-464. DOI: 10.1016/j.trd.2004.08.004

Litman, T., Burwell, D. (2006), "Issues in sustainable transportation", International Journal of Global Environmental Issues, Vol. 6 No. 4, pp. 331-347. DOI: 10.1504/IJGENVI.2006.010889

Lehtinen, J., Ahola, T. (2010) "Is performance measurement suitable for an extended enterprise?", International Journal of Operations and Production Management, 30 (2),181-204. DOI: http://dx.doi.org/10.1108/01443571011018707

Lindholm, M. (2012) "How Local Authority Decision Makers Address Freight Transport in the Urban Area”, Procedia - Social and Behavioral Sciences, Vol. 39, pp. 134-145. DOI: 10.1016/j.sbspro.2012.03.096

Macharis, C., De Witte, A., Ampe, J. (2009) "The multi- actor, multi- criteria analysis methodology (MAMCA) for the evaluation of transport projects: Theory and practice", Journal of Advanced Transportation, pp. 183-202. DOI: 10.1002/atr.5670430206

Manville, C., Cochrane, G., Cave, J., Millard, J., Pederson, J.K., Thaarup, R.K., Liebe, A., Wissner, M., Massink, R. and Kotterink, B. (2014), "Mapping smart cities in the EU", European Parliament, available at: http://www.europarl.europa.eu/studies (accessed 27.07.15).

Marshall, D., McCarthy, L., Heavey, C., McGrath, P. (2015) "Environmental and social supply chain management sustainability practices: construct development and measurement", Production Planning \& Control Vol. 26, Iss. 8, pp. 673-690. DOI: 10.1080/09537287.2014.963726

Martin, B.S (2000) 'The Irish Urban System and its Dynamics'. Available at: www.irishspatialstrategy.ie/docs/report8.pdf (accessed 21.10.2015)

MIT (2014) "City Science”, available at: http://cities.media.mit.edu/research/mobility-networks (accessed 27.07.15).

Montoya-Torres, J. R., Gutierrez-Franco, E. and Blanco, E. E. (2014) "Conceptual framework for measuring carbon footprint in supply chains", Production Planning and Control, published on-line: March $10^{\text {th }}$. DOI: $10.1080 / 09537287.2014 .894215$

Muñuzuri, J., Larraneta, J., Onieva, L. Cortés, P. (2005) "Solutions applicable by local administrations for urban logistics improvement". Cities, Vol. 22, No. 1, pp. 15-28. DOI: 10.1016/j.cities.2004.10.003 
Muñuzuri, J., Cortés, P., Onieva, L., Guadix, J. (2009), "Modeling Freight Delivery Flows: Missing Link of Urban Transport Analysis", Journal of Urban Planning and Development, Vol. 135 No. 3, pp.

91- 99. DOI: http://dx.doi.org/10.1061/(ASCE)UP.1943-5444.0000011

Organisation for Economic Co-operation and Development (OECD) (2003) "Delivering the goods: 21st Century Challenges to Urban Goods Transport". Technical report. Paris: OECD, ISBN: 9789264102804

Österle, I., Aditjandra, P.T., Vaghi, C., Grea, G., Zunder, T.H. (2015) "The role of a structured stakeholder consultation process within the establishment of a sustainable urban supply chain", Supply Chain Management: An International Journal, Vol. 20, No. 3, pp. 284-299. http://dx.doi.org/10.1108/SCM-05-2014-0149

Ott, H. E., Sterk, W., Watanabe, R. (2008) "The Bali roadmap: new horizons for global climate policy", Climate Policy, Vol. 8 No. 1, pp. 91-95. DOI: 10.3763/cpol.2007.0510

Parasuraman, A., Zeithaml, V., Berry, L. (1988), "SERVQUAL: A multiple item scale for measuring consumer perceptions of service quality", Journal of Retailing, Vol. 64, No.1, pp. 12-40.

Patier, D. (2002) La logistique dans la ville, Paris / France: CELSE Editor

Punakivi, M., Yrjölä, H., Holmström, J. (2001) "Solving the last-mile issue: reception box or delivery box?", International Journal of Physical Distribution \& Logistics Management, Vol. 31, 6, pp. 427-439. DOI: $10.1108 / 09600030110399423$

PWC (2013), "The outlook for UK mail volumes to 2023", Available at: http://www.royalmailgroup.com/sites/default/files/The\%20outlook\%20for\%20UK\%20mail\%20volumes \%20to\%202023.pdf

Rodrigue, J-P., Comtois, C., Slack, B. (2009) The geography of transport systems. 2nd Aufl. London: Routledge. ISBN: 0415483247.

Rossi, S., Colicchia, C., Cozzolino, A., Christopher, M. (2013) "The logistics service providers in ecoefficiency innovation: an empirical study", Supply Chain Management: An International Journal, Vol. 18 Iss: 6, pp.583-603. DOI: 10.1108/SCM-02-2012-0053

Russo, F., Comi, A. (2011) "Measures for sustainable freight transportation at urban scale: expected goals and tested results in Europe", Journal of Urban Planning and Development, Vol. 137, pp. 142152. DOI: $10.1061 /($ ASCE)UP.1943-5444.0000052

Sarasvathy, S.D., Dew, N. (2005) 'New Market Creation through Transformation', Journal of Evolutionary Economics, Vol.15, pp. 533-565. DOI: 10.1007/s00191-005-0264-x

Sonntag, H. and Meimbresse, B. (2008), "Introduction to Task 3.2 Modelling Approaches". 4th BESTUFS Round Table - Urban freight data harmonisation and modelling. Available at: http://www.bestufs.net/download/Roundtables/2nd_Roundtable_Wildau06/BESTUFS_Wildau_Jun06 Sonntag_TFH.pdf

Srai, J.S., Gregory, M. (2008), "A Supply Network Configuration Perspective on International Supply Chain Development", International Journal of Operations and Production Management, Vol. 28 No.5, pp. 386-411. DOI: 10.1108/01443570810867178

Srai, J.S. (2011). "Supply network integration in multi-organizational network systems", International Journal of Manufacturing Research, Vol. 6, No. 2, pp. 122-133. DOI: 10.1504/IJMR.2011.040007

Srai, J.S., Harrington, T.S. (2014) 'E-commerce-driven last-mile logistics networks', in, 'Capturing value from global networks: strategic approaches to designing international production, supply and service operations', University of Cambridge, Institute for Manufacturing, pp. 67-71. ISBN: 978-1902546-30-8 
Stathopoulos, A., Valeri, E., Marcucci, E., Gatta, V., Nuzzolo, A., Comi, A., (2011). Urban freight policy innovation for Rome's LTZ: a stakeholder perspective. In: Macharis, C., Melo, S. (Eds.), City Distribution and Urban Freight Transport: Multiple Perspectives. Edward Elgar Publisher, Cheltenham, pp. $75-101$.

Stefansson, G. (2002) "Business-to-business data sharing: A source for integration of supply chains", Int. J. Production Economics 75, pp.135-146. DOI: 10.1016/S0925-5273(01)00187-6

Stevenson, M. Spring, M. (2007) "Flexibility from a supply chain perspective: definition and review", International Journal of Operations \& Production Management, Vol. 27 No 7, pp. 685-713. DOI: $10.1108 / 01443570710756956$

Stewart, G. (1995) "Supply chain performance benchmarking study reveals keys to supply chain excellence". Logistics Information Management, Vol. 8 No. 2, pp. 38-44. DOI:

$10.1108 / 09576059510085000$

Swamidass, P. (2000), Encyclopedia of Production and Manufacturing Management, Edited by Paul Swamidass, Kluwer Academic Publishers, ISBN: 0-7923-8630-2

Taniguchi, E., Thompson, R. G. and Yamada, T., (2001), "Recent advances in modelling City Logistics", in Taniguchi, E., Thompson, R. G. (Eds). City Logistics II, Institute of Systems Science Research, Japan, p. 3-33.

Taniguchi, E., Tamagawa, D. (2005), "Evaluating city logistics measures considering the behavior of several stakeholders", Journal of the Eastern Asia Society for Transportation Studies, Vol. 6, pp. 30623076. DOI: 10.11175/easts.6.3062

Tseng, Y., Yue, W., Taylor, M. (2005) "The role of transportation in logistics chain". (Ed.): Proceedings of the eastern Asia society for transportation studies, pp. 1657-1672. Available at:

https://www.siam.org/journals/plagiary/1657.pdf

UN (2009) Copenhagen Accord. Available at: http://unfccc.int/resource/docs/2009/cop15/eng/l07.pdf

UN-HABITAT (2015), "International Guidelines on Urban and Territorial Planning", Available at: http://unhabitat.org/books/international-guidelines-on-urban-and-territorial-planning/ (accessed 26.11.2015)

UN-HABITAT (2009), "Climate change: The role of cities", Available at: http://www.unep.org/urban environment/PDFs/RoleofCities 2009.pdf (accessed 26.11.2015)

UPS (2013) "UPS Pulse of the Online Shopper Study", Available at:

https://www.ups.com/media/en/gb/UPS Pulse of the Online Shopper.pdf (accessed 01.12.2015)

Van Duin, J.H.R (1997) "Evaluation and evolution of the city distribution concept" in "Urban transport and the environment for the $21^{\text {st }}$ century III", WIT Press, Southampton, pp. 149-158.

Van Duin, J.H.R, Quak, H. J. (2007) "City logistics: a chaos between research and policy making? A review", Urban Transport XIII-Urban Transport and the Environment in the 21st Century, pp. 135-146. ISBN: 9781845640873

Voss, C. (2009) 'Case Research in Operations Management', in Karlsson, C. (Ed.), Researching Operations Management, Routledge, New York, pp. 162-196.

Ward, P., McCreery, J., Ritzman, L. Sharma, D. (1998) "Competitive priorities in operations management”, Decision Sciences, Vol. 29 No. 4, pp. 1035-1046. DOI: 10.1111/j.15405915.1998.tb00886.x

White, G. (1996) "A survey and taxonomy of strategy-related performance measures for manufacturing", International Journal of Operations \& Production Management, Vol. 16 No. 3, pp. $42-$ 61. DOI: $10.1108 / 01443579610110486$ 
Yeniyurt, S. (2003), "A literature review and integrative performance measurement framework for multinational companies", Marketing Intelligence \& Planning, Vol. 21 No. 3, pp. 134-142. DOI: $10.1108 / 02634500310474957$

Yin, R. K. (2009), Case Study Research - Design and Methods. Sage, Thousand Oaks.

Yu, W. (2015) "The effect of IT-enabled supply chain integration on performance", Production Planning \& Control, Volume 26, Issue 12, pp.945-957. DOI: 10.1080/09537287.2014.1002021 
Table 1

\begin{tabular}{|c|c|c|c|c|c|c|c|c|}
\hline \multirow[b]{2}{*}{ Overview } & \multirow[b]{2}{*}{$\begin{array}{l}\text { Design } \\
\text { criteria }\end{array}$} & \multirow[b]{2}{*}{ Definition examples } & \multicolumn{2}{|c|}{ Consumer } & \multicolumn{2}{|c|}{ Industrial } & \multicolumn{2}{|c|}{ Institutional } \\
\hline & & & 'Customer' & 'Inhabitant' & 'Shipper' & $\begin{array}{l}\text { 'Freight } \\
\text { Carrier' }\end{array}$ & $\begin{array}{c}\text { 'Local } \\
\text { Authority' }\end{array}$ & $\begin{array}{l}\text { 'Regional } \\
\text { Government' }\end{array}$ \\
\hline \multirow{5}{*}{$\begin{array}{l}\text { Financial and } \\
\text { Non-financial; } \\
\text { location of } \\
\text { measures } \\
\text { (Stewart, } \\
\text { 1995; Milgate, } \\
\text { 2001) }\end{array}$} & $\begin{array}{c}\text { Delivery } \\
\text { performance }\end{array}$ & $\begin{array}{l}\text { Delivery to request and to-commit dates, order fill lead time, } \\
\text { throughput time, \% of late deliveries, average lateness }\end{array}$ & & & & & & \\
\hline & Logistics cost & Total logistics cost, Order management cost & & & & & & \\
\hline & $\begin{array}{c}\text { Asset } \\
\text { management }\end{array}$ & Inventory days of supply, Days of sale outstanding & & & & & & \\
\hline & Flexibility & Production & & & & & & \\
\hline & Responsiveness & Re-plan and make cycle times & & & & & & \\
\hline \multirow{4}{*}{$\begin{array}{l}\text { Performance } \\
\text { measure } \\
\text { components } \\
\text { (Beamon, } \\
\text { 1998) }\end{array}$} & $\begin{array}{l}\text { Customer } \\
\text { responsiveness }\end{array}$ & $\begin{array}{l}\text { Time required to produce; Number of orders delivered on time; } \\
\text { Number of units produced; Fill rate; Stock-out probability; Number } \\
\text { of backorders; Number of stock-outs; Customer response time; } \\
\text { Average lead time; Shipping errors; Customer complaints }\end{array}$ & & & & & & \\
\hline & Cost & Manufacturing, distribution and inventory and total cost & & & & & & \\
\hline & Profitability & Return on Investment (ROI) & & & & & & \\
\hline & Flexibility & Volume, delivery, mix, new product flexibility & & & & & & \\
\hline \multirow{6}{*}{$\begin{array}{l}\text { Location of } \\
\text { measures and } \\
\text { decision } \\
\text { making levels } \\
\text { within supply } \\
\text { chain: } \\
\text { strategic, } \\
\text { tactical, } \\
\text { operational, } \\
\text { measurement } \\
\text { base } \\
\text { (Gunasekaran } \\
\text { et al. 2001) }\end{array}$} & $\begin{array}{l}\text { Customer } \\
\text { service } \\
\text { satisfaction }\end{array}$ & $\begin{array}{l}\text { Flexibility; Customer query time; Post transaction measures of } \\
\text { customer service; Customer perception of service }\end{array}$ & & & & & & \\
\hline & $\begin{array}{l}\text { Supply chain } \\
\text { partnerships }\end{array}$ & $\begin{array}{l}\text { Level and degree of information sharing, extent of mutual co- } \\
\text { operation leading to improved quality, extent of mutual assistance } \\
\text { in problem solving efforts }\end{array}$ & & & & & & \\
\hline & $\begin{array}{l}\text { Delivery } \\
\text { performance }\end{array}$ & $\begin{array}{l}\text { Delivery-to-request data, delivery-to-commit date, order fill lead } \\
\text { time, number of faultess notes invoiced, flexibility of delivery } \\
\text { systems to meet customer needs }\end{array}$ & & & & & & \\
\hline & $\begin{array}{l}\text { Finance and } \\
\text { costs }\end{array}$ & $\begin{array}{l}\text { Total distribution cost, delivery lead time, cost associated with } \\
\text { assets and ROI, total inventory cost, total cash flow time }\end{array}$ & & & & & & \\
\hline & $\begin{array}{l}\text { Production level } \\
\text { measures }\end{array}$ & $\begin{array}{l}\text { Range of products and services, effectiveness of scheduling } \\
\text { techniques, capacity utilisation }\end{array}$ & & & & & & \\
\hline & $\begin{array}{l}\text { Planned order } \\
\text { procedures }\end{array}$ & Order lead time, Customer order path & & & & & & \\
\hline \multirow{2}{*}{$\begin{array}{l}\text { Financial and } \\
\text { Non-financial } \\
\text { (De Toni and }\end{array}$} & $\begin{array}{l}\text { Quality } \\
\text { performance }\end{array}$ & $\begin{array}{l}\text { Including Customer satisfaction; Technical assistance; Returned } \\
\text { goods }\end{array}$ & & & & & & \\
\hline & $\begin{array}{l}\text { Cost } \\
\text { performance }\end{array}$ & $\begin{array}{l}\text { Including e.g. labour and energy costs, material consumption, } \\
\text { inventory and WIP levels) }\end{array}$ & & & & & & \\
\hline
\end{tabular}




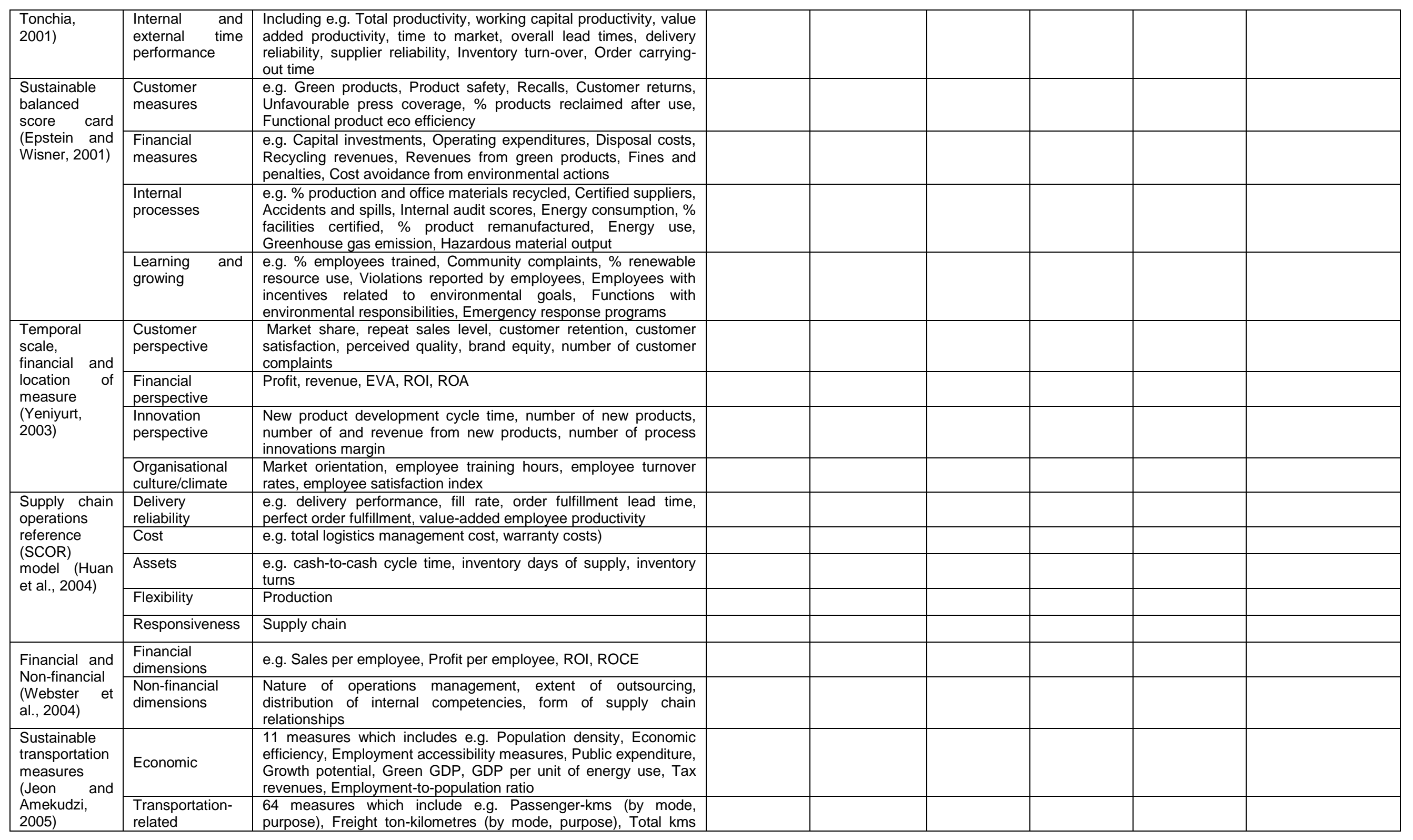




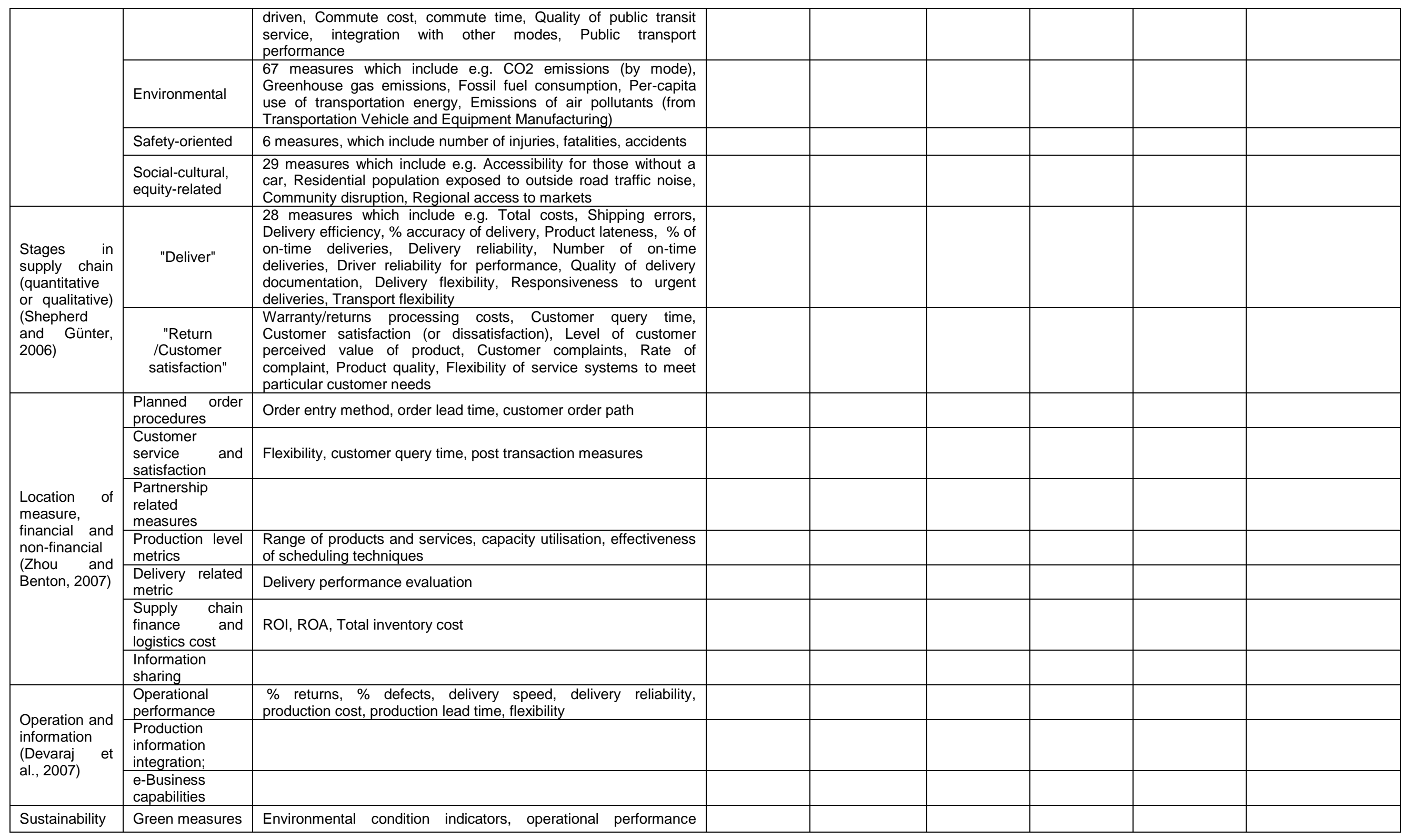




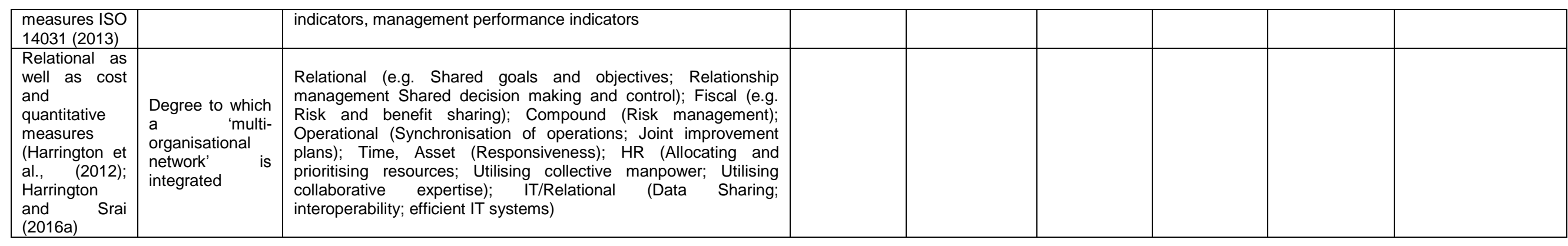


Table 2

\begin{tabular}{|c|c|c|c|c|c|c|c|c|}
\hline \multicolumn{3}{|c|}{ Consumer perspective } & \multicolumn{6}{|c|}{ B2C 'last mile' - defined by a specific urban system } \\
\hline \multicolumn{2}{|c|}{ Dimensions } & \multirow{2}{*}{$\begin{array}{c}\text { Design criteria } \\
\text { Pick up cost } \\
\text { Service price } \\
\text { Communication costs } \\
\text { Compensation for poor } \\
\text { service levels }\end{array}$} & \multirow{2}{*}{$\begin{array}{c}\begin{array}{l}\text { Upstream } \\
\text { logistics }\end{array} \\
- \\
-\end{array}$} & \multirow{2}{*}{$\begin{array}{c}\text { Transit point } \\
\text { - }\end{array}$} & \multirow{2}{*}{\begin{tabular}{|c|}
$\begin{array}{c}\text { Transportation } \\
\text { to drop point }\end{array}$ \\
-
\end{tabular}} & \multirow[t]{2}{*}{ Drop point } & \multirow{2}{*}{$\begin{array}{c}\begin{array}{c}\text { Pick up } \\
\text { distance }\end{array} \\
\begin{array}{c}\text { Pick up cost } \\
\text { No. of pick ups }\end{array}\end{array}$} & \multirow{2}{*}{$\begin{array}{c}\text { Destination point } \\
\text { Service price } \\
\text { Communication costs } \\
\text { Compensation for poor } \\
\text { service levels } \\
\text { (insurance) }\end{array}$} \\
\hline Cost & Performance & & & & & & & \\
\hline & Utilisation & Pick up connection & - & - & - & & Means of transport & \\
\hline \multirow{3}{*}{ Quality } & Information & $\begin{array}{l}\text { Complete order tracking } \\
\text { Service point availability } \\
\text { Friendly and competent } \\
\text { service point } \\
\text { Customer connectivity }\end{array}$ & - & - & - & Complete traceability & & $\begin{array}{l}\text { Single point of contact } \\
\text { Notification of } \\
\text { unexpected events } \\
\text { Information quality: } \\
\text { completeness, ease of } \\
\text { understanding, } \\
\text { personalisation, } \\
\text { relevance, security }\end{array}$ \\
\hline & Material flow & $\begin{array}{c}\text { Pick up distance } \\
\text { Availability of required service }\end{array}$ & - & - & - & & $\begin{array}{l}\text { Pick up distance } \\
\text { No. of pick ups }\end{array}$ & $\begin{array}{l}\text { Availability of: } \\
\text { - required service } \\
\text { - reverse logistics } \\
\text { - attended delivery }\end{array}$ \\
\hline & Service & Additional services & - & - & - & & & Additional services \\
\hline Time & Process & $\begin{array}{c}\text { Total lead time } \\
\text { Handover time } \\
\text { Delivery frequency } \\
\text { Pick up time }\end{array}$ & - & - & - & $\begin{array}{c}\text { Total lead time } \\
\text { Delivery frequency }\end{array}$ & Pick up time & Handover time \\
\hline \multirow{4}{*}{ Flexibility } & Cost & $\begin{array}{l}\text { Pricing models } \\
\text { Drop point connection } \\
\text { Payment options }\end{array}$ & - & - & - & & Means of transport & $\begin{array}{l}\text { Range of prices } \\
\text { (services) } \\
\text { Payment options }\end{array}$ \\
\hline & Volume & $\begin{array}{c}\text { Quantity/size of goods } \\
\text { (options) }\end{array}$ & - & - & - & Storage space & & Quantity/size of goods \\
\hline & Range & \begin{tabular}{|c|} 
Delivery of goods (type) \\
Customised services \\
- green option \\
- after purchase options \\
Delivery directions \\
\end{tabular} & - & - & - & $\begin{array}{l}\text { Storage characteristics } \\
\text { Drop point options }\end{array}$ & & $\begin{array}{l}\text { Range of services } \\
\text { Types of goods } \\
\text { 'Green' option availability } \\
\text { After-purchase options } \\
\text { (Time, destination) }\end{array}$ \\
\hline & Time & \begin{tabular}{|c|} 
Delivery time window \\
Accessibility of drop point \\
Accessibility of service point \\
Availability of transport options
\end{tabular} & - & - & - & $\begin{array}{l}\text { Delivery time window } \\
\text { Pick up time window }\end{array}$ & $\begin{array}{l}\text { Availability of } \\
\text { transport options }\end{array}$ & $\begin{array}{l}\text { Accessibility of service } \\
\text { point }\end{array}$ \\
\hline \multirow{4}{*}{ Reliability } & Cost & Additional costs & - & - & - & & & Communication costs \\
\hline & Time & $\begin{array}{l}\text { Deliveries on-time } \\
\text { Service point contact time }\end{array}$ & - & - & - & & & Service point contact time \\
\hline & Place & $\begin{array}{l}\text { Total lost parcel rate } \\
\text { Deliveries to destination }\end{array}$ & - & - & - & \begin{tabular}{|c|} 
Total lost parcels \\
Deliveries to destination
\end{tabular} & & \\
\hline & Quality & $\begin{array}{l}\text { Total damaged parcel rate } \\
\text { Failed deliveries }\end{array}$ & - & - & - & & & Failed deliveries \\
\hline
\end{tabular}


Table 3

\begin{tabular}{|c|c|c|c|c|c|c|c|c|}
\hline \multicolumn{3}{|c|}{ Industrial perspective } & \multicolumn{6}{|c|}{ B2C 'last mile' - defined by a specific urban system } \\
\hline \multicolumn{2}{|c|}{ Dimensions } & Design criteria & Upstream logistics & Transit point & $\begin{array}{c}\text { Transportation to drop } \\
\text { point }\end{array}$ & Drop point & $\begin{array}{l}\text { Pick up } \\
\text { distance }\end{array}$ & Destination point \\
\hline \multirow[t]{2}{*}{ Cost } & Performance & \begin{tabular}{|l} 
Revenue \\
Operational costs \\
- EVA \\
- ROI \\
- ROA
\end{tabular} & \begin{tabular}{|l|} 
Parcel kms \\
Consumption rate \\
Load factor (weight, size) \\
Efficiency of vehicle use \\
Repair
\end{tabular} & $\begin{array}{l}\text { Occupation rate } \\
\text { Maintenance }\end{array}$ & \begin{tabular}{|l} 
Parcel kms \\
Consumption rate \\
Load factor (weight, size) \\
Efficiency of vehicle use \\
Repair
\end{tabular} & Maintenance & & Revenue \\
\hline & Utilisation & \begin{tabular}{|l|} 
Assets \\
- fixed cost \\
- variable costs \\
\end{tabular} & \begin{tabular}{|l|} 
Labour \\
Vehicles
\end{tabular} & \begin{tabular}{|l|} 
Labour \\
Buildings \\
Facilities \\
\end{tabular} & \begin{tabular}{|l|} 
Labour \\
Vehicles
\end{tabular} & \begin{tabular}{|l|} 
Labour \\
Buildings \\
Facilities \\
\end{tabular} & & \begin{tabular}{|l|}
$\begin{array}{l}\text { (Pick up distance }=0 \text { ) } \\
\text { Labour } \\
\text { Facilties }\end{array}$ \\
\end{tabular} \\
\hline \multirow{3}{*}{ Quality } & Information & $\begin{array}{l}\text { Inbound connectivity } \\
\text { internal firm connectivity } \\
\text { Traffic network integration } \\
\text { Customer connectivity } \\
\text { Service use } \\
\end{array}$ & \begin{tabular}{|l|} 
Traceability \\
Accessible traffic information \\
Timeliness, security
\end{tabular} & \begin{tabular}{|l} 
Traceability \\
Completeness of \\
delivery data
\end{tabular} & \begin{tabular}{|l|} 
Traceability \\
Accessible traffic information \\
Timeliness, security
\end{tabular} & Traceability & & $\begin{array}{l}\text { Communication channels } \\
\text { Service use }\end{array}$ \\
\hline & Material flow & $\begin{array}{l}\text { Transport technology } \\
\text { Labour quality } \\
\text { Standardisation }\end{array}$ & $\begin{array}{l}\text { Transport vehicle (av. age) } \\
\text { Driver experience }\end{array}$ & \begin{tabular}{|l} 
Age of facilities \\
Distribution, \\
consolidation skills
\end{tabular} & & & & \\
\hline & Service & $\begin{array}{l}\text { Customer satisfaction } \\
\text { (defined by customer) } \\
\text { Service use/parcel } \\
\text { Market share } \\
\end{array}$ & & & & & & \\
\hline Time & Process & \begin{tabular}{|l|} 
Total lead time \\
Delivery frequency \\
Process times \\
(transport, consolidation, \\
throughput, storage, \\
opening, handover, \\
load/unload, service) \\
\end{tabular} & $\begin{array}{l}\text { Upstream leadtime } \\
\text { Transport time }\end{array}$ & $\begin{array}{l}\text { Switching time } \\
\text { Throughput time } \\
\text { Consolidation time } \\
\text { Storage time }\end{array}$ & & $\begin{array}{l}\text { Total lead time } \\
\text { Load/unload time } \\
\text { Handover time } \\
\text { Delivery frequency }\end{array}$ & & $\begin{array}{l}\text { Service time } \\
\text { (assembly, installation } \\
\text { times etc.) }\end{array}$ \\
\hline \multirow{4}{*}{ Flexibility } & Cost & Variable/fixed costs & 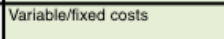 & Variable/fixed costs & Variable/fixed costs & $\begin{array}{l}\text { Variableffixed costs } \\
\text { nation }\end{array}$ & & \\
\hline & Volume & \begin{tabular}{|l|} 
Delivery of goods \\
(number, size) \\
Capacity
\end{tabular} & & & & Storage space & & \\
\hline & Range & \begin{tabular}{|l|} 
Delivery of goods \\
(type) \\
Range of services \\
Assignment of employees
\end{tabular} & & & & $\begin{array}{l}\text { Storage characteristics } \\
\text { Drop point options }\end{array}$ & & \begin{tabular}{|l} 
Range of services \\
\end{tabular} \\
\hline & Time & $\begin{array}{l}\text { Operating time } \\
\text { Labour time } \\
\text { Delivery time window } \\
\text { Accessibility time window }\end{array}$ & & & & & & $\begin{array}{l}\text { Accessibility time window } \\
\text { Labour contract } \\
\text { composition }\end{array}$ \\
\hline \multirow{4}{*}{ Reliability } & Cost & $\begin{array}{l}\text { Real cost/target cost } \\
\text { Growth }\end{array}$ & Real costtiarget cost & Real costharget cost & Real costharget cost & Real costharget cost & & $\begin{array}{l}\text { lower performance costs } \\
\text { Growth (revenue delta) }\end{array}$ \\
\hline & Time & $\begin{array}{l}\text { Process time deviation } \\
\text { Delivery tries } \\
\text { Deliveries on-time }\end{array}$ & $\begin{array}{l}\text { Upstream leadtime deviation } \\
\text { Transport time deviation }\end{array}$ & $\begin{array}{l}\text { Switching time deviation } \\
\text { Throughput time deviation }\end{array}$ & & \begin{tabular}{|l|} 
Total leadtime deviation \\
Handover time deviation \\
Delivery tries (av.) \\
Deliveries on-time (av.)
\end{tabular} & & \\
\hline & Place & \begin{tabular}{|l|} 
Total lost parcel rate \\
Deliveries to destination
\end{tabular} & Lost parcel rate & Lost parcel rate & Lost parcel rate & $\begin{array}{l}\text { Total lost parcel rate } \\
\text { Deliveries to destination } \\
\text { (rate) }\end{array}$ & & \\
\hline & Quality & $\begin{array}{l}\text { Total damaged parcel rate } \\
\text { Customer complaints }\end{array}$ & Damaged parcel rate & Damaged parcel rate & Damaged parcel rate & Damaged parcel rate & & Customer complaints \\
\hline
\end{tabular}


Table 4

\begin{tabular}{|c|c|c|c|c|c|c|c|}
\hline \multicolumn{2}{|c|}{ Institutional perspective } & \multicolumn{6}{|c|}{ B2C 'last mile' - defined by a specific urban system } \\
\hline Dimensions & Design criteria & Upstream logistics & Transit point & $\begin{array}{l}\text { Transportation to } \\
\text { drop point }\end{array}$ & Drop point & Pick up distance & Destination point \\
\hline \multirow{4}{*}{ Social } & Reduction of congestion & \begin{tabular}{|l|} 
Travel time (peak) \\
Vehicle occupancy \\
No. of operating vehicles
\end{tabular} & & \begin{tabular}{|l|} 
Travel time (peak) \\
Vehicle occupancy \\
No. of operating vehicles
\end{tabular} & & \begin{tabular}{|l} 
Pick-up (by vehicle) \\
Travel time (peak) \\
No. of pick-ups \\
\end{tabular} & \\
\hline & Reduction of road accidents & \begin{tabular}{l|} 
Driver training \\
No. of operating vehicles
\end{tabular} & & $\begin{array}{l}\text { Driver training } \\
\text { No. of operating vehicles }\end{array}$ & & No. of pick-ups (by vehicle) & \\
\hline & $\begin{array}{l}\text { Reduction of freighttraffic } \\
\text { volumes }\end{array}$ & \begin{tabular}{|l|} 
Vehicle kms/parcel \\
Operating vehicles \\
Occupancy of vehicles (av.)
\end{tabular} & & $\begin{array}{l}\text { Vehicle kms/parcel } \\
\text { Operating vehicles } \\
\text { Occupancy of vehicles (av.) }\end{array}$ & & $\begin{array}{l}\text { Pick-up distance } \\
\text { Pick-up by own vehicle }\end{array}$ & \\
\hline & Reduction of interferences & \begin{tabular}{|l|l} 
Congestion \\
Road accidents
\end{tabular} & \begin{tabular}{|l} 
Parking \\
Load/unload times
\end{tabular} & \begin{tabular}{|l|} 
Congestion \\
Road accidents \\
\end{tabular} & \begin{tabular}{|l|} 
Parking \\
Load/unload times
\end{tabular} & \begin{tabular}{|l} 
Congestion \\
Road accidents
\end{tabular} & \\
\hline \multirow[b]{2}{*}{ Technological } & Increase in low-emission vehicles & Emission rate (av.) & & Emission rate (av.) & & & \\
\hline & \begin{tabular}{|l|} 
Routing software \\
innovation'traffic network \\
integration
\end{tabular} & & & $\begin{array}{l}\text { Soffware implemenatation } \\
\text { rates }\end{array}$ & & & \\
\hline \multirow{4}{*}{ Environmental } & Reduction of land use & $\begin{array}{l}\text { No. of operating vehicles } \\
\text { Vehicle occupancy }\end{array}$ & Warehouse occupancy & $\begin{array}{l}\text { No. of operating vehicles } \\
\text { Vehicle oocupancy }\end{array}$ & Occupancy of drop box & & \\
\hline & \begin{tabular}{|l|}
$\begin{array}{l}\text { Reduction of resource use } \\
\text { (fuel, water, energy) }\end{array}$ \\
\end{tabular} & $\begin{array}{l}\text { Vehicle kms/parcel } \\
\text { Consumption rate } \\
\text { Fuel type }\end{array}$ & $\begin{array}{l}\text { Water use } \\
\text { Energy use }\end{array}$ & $\begin{array}{l}\text { Vehicle kms/parcel } \\
\text { Consumption rate } \\
\text { Fuel type }\end{array}$ & $\begin{array}{l}\text { Water use } \\
\text { Energy use }\end{array}$ & $\begin{array}{l}\text { Pick-up distance (by vehicle) } \\
\text { Consumption rate } \\
\text { Fuel type }\end{array}$ & \\
\hline & Reduction of noise emissions & $\begin{array}{l}\text { No. of operating vehicles } \\
\text { Traffic speed } \\
\text { Vehicle characteristics }\end{array}$ & & $\begin{array}{l}\text { No. of operating vehicles } \\
\text { Traffic speed } \\
\text { Vehicle characteristics }\end{array}$ & & & \\
\hline & Reduction of pollutants & $\begin{array}{l}\text { Vehicle kms/parcel } \\
\text { Emission rate }\end{array}$ & & $\begin{array}{l}\text { Vehicle kmsiparcel } \\
\text { Emission rate }\end{array}$ & & & \\
\hline \multirow{9}{*}{ Economical } & Reduction of congestion & \begin{tabular}{|l|} 
Travel time (peak) \\
Vehicle occupancy \\
No. of operating vehicles
\end{tabular} & & \begin{tabular}{|l|} 
Travel time (peak) \\
Vehicle occupancy \\
No. of operating vehicles
\end{tabular} & & \begin{tabular}{|l} 
Pick-up (by vehicle) \\
Travel time (peak) \\
No. of pick-ups \\
\end{tabular} & \\
\hline & Reduction of road accidents & $\begin{array}{l}\text { Driver training } \\
\text { No. of operating vehicles }\end{array}$ & & $\begin{array}{l}\text { Driver training } \\
\text { No. of operating vehicles }\end{array}$ & & No. of pick-ups (by vehicle) & \\
\hline & $\begin{array}{l}\text { Reduction of freight/traffic } \\
\text { volumes }\end{array}$ & \begin{tabular}{|l|} 
Vehicle kms/parcel \\
Operating vehicles \\
Occupancy of vehicles (av.)
\end{tabular} & & $\begin{array}{l}\text { Vehicle kms/parcel } \\
\text { Operating vehicles } \\
\text { Occupancy of vehicles (av.) }\end{array}$ & & \begin{tabular}{|l} 
Pick-up distance \\
Pick-up by own vehicle
\end{tabular} & \\
\hline & Reduction of interferences & \begin{tabular}{|l|l|} 
Congestion \\
Road accidents
\end{tabular} & $\begin{array}{l}\text { Parking } \\
\text { Load/unload times }\end{array}$ & $\begin{array}{l}\text { Congestion } \\
\text { Road accidents }\end{array}$ & \begin{tabular}{|l|} 
Parking \\
Load/unload times
\end{tabular} & $\begin{array}{l}\text { Congestion } \\
\text { Road accidents }\end{array}$ & \\
\hline & Reduction of land use & $\begin{array}{l}\begin{array}{l}\text { No. of operating vehicles } \\
\text { Vehicle occupancy }\end{array} \\
\end{array}$ & Warehouse occupancy & $\begin{array}{l}\text { No. of operating vehicles } \\
\text { Vehicle occupancy }\end{array}$ & Occupancy of drop box & & \\
\hline & \begin{tabular}{|l|} 
Reduction of resource use \\
(fuel, water, energy)
\end{tabular} & $\begin{array}{l}\text { Vehicle kms/parcel } \\
\text { Consumption rate } \\
\text { Fuel type }\end{array}$ & $\begin{array}{l}\text { Water use } \\
\text { Energy use }\end{array}$ & $\begin{array}{l}\text { Vehicle kms/parcel } \\
\text { Consumption rate } \\
\text { Fuel type }\end{array}$ & $\begin{array}{l}\text { Water use } \\
\text { Energy use }\end{array}$ & $\begin{array}{l}\text { Pick-up distance (by vehicle) } \\
\text { Consumption rate } \\
\text { Fuel type }\end{array}$ & \\
\hline & Reduction of noise emissions & $\begin{array}{l}\text { No. of operating vehicles } \\
\text { Traffic speed } \\
\text { Vehicle characteristics }\end{array}$ & & $\begin{array}{l}\text { No. of operating vehicles } \\
\text { Traffic speed } \\
\text { Vehicle characteristics }\end{array}$ & & & \\
\hline & Reduction of pollutants & $\begin{array}{l}\text { Vehicle kms/parcel } \\
\text { Emission rate }\end{array}$ & & $\begin{array}{l}\text { Vehicle kms/parcel } \\
\text { Emission rate }\end{array}$ & & & \\
\hline & \begin{tabular}{|l|}
$\begin{array}{l}\text { Decreasing investment } \\
\text { Increasing revenue }\end{array}$ \\
\end{tabular} & & Assets & Assets & Assets & & Growth (revenue) \\
\hline \multirow{3}{*}{ Political } & Responsible behaviour & Better than the norm & Better than the norm & Better than the norm & Better than the norm & & \\
\hline & $\begin{array}{l}\text { Creation of new employment } \\
\text { opportunities }\end{array}$ & $\begin{array}{l}\text { No. and type of new job } \\
\text { opportunities }\end{array}$ & $\begin{array}{l}\text { No. and type of new } \\
\text { job opportunities }\end{array}$ & $\begin{array}{l}\text { No. and type of new job } \\
\text { opportunities }\end{array}$ & & & $\begin{array}{l}\text { No. and type of new job } \\
\text { opportunities }\end{array}$ \\
\hline & Raise quality of life standards & & & & & & \begin{tabular}{|l|} 
Range of services \\
Customer satisfaction
\end{tabular} \\
\hline
\end{tabular}


Table 5

\begin{tabular}{|c|c|c|}
\hline Interviewee & Perspective & Description \\
\hline 1 & $\begin{array}{l}\text { Customer } \\
\text { archetype A }\end{array}$ & $\begin{array}{l}\text { Archetype A uses service exclusively for personal goods delivery, using both 'delivery' and 'pick- } \\
\text { up' options - representing a general consumer perspective }\end{array}$ \\
\hline 2 & $\begin{array}{l}\text { Customer } \\
\text { archetype B }\end{array}$ & $\begin{array}{l}\text { Archetype B uses 'pick-up' service in the context of e.g. small-to-medium sized enterprises } \\
\text { (SMEs) that may be run from a home residence - representing a 'consumer-industry' perspective }\end{array}$ \\
\hline 3 & $\begin{array}{l}\text { Customer } \\
\text { archetype C }\end{array}$ & $\begin{array}{l}\text { Archetype C uses service exclusively for personal goods delivery, via the sustainable vehicle } \\
\text { service option }\end{array}$ \\
\hline 4 & Industrial & Managing Director, Courier firm and PCC operating company \\
\hline 5 & Industrial & Operations Director, Courier firm and PCC operating company \\
\hline 6 & Industrial & $\begin{array}{l}\text { Technology developer, responsible for PCC portal and real-time vehicle tracking software } \\
\text { elements of the 'last-mile' solution }\end{array}$ \\
\hline 7 & Industrial & $\begin{array}{l}\text { Green Business Forum (GBF) officer (GBF is a partnership between local businesses and the } \\
\text { local authority within the geographical area of the case study) }\end{array}$ \\
\hline 8 & Institutional & LA, Local Authority officer responsible for the Planning Environment in which the PCC operates \\
\hline 9 & Institutional & $\begin{array}{l}\text { LA, Local Authority officer responsible for Technical Standards in the geographical area where the } \\
\text { PCC operates }\end{array}$ \\
\hline 10 & Institutional & $\begin{array}{l}\text { LA, Local Authority officer responsible for Infrastructure Delivery in the geographical area where } \\
\text { the PCC operates }\end{array}$ \\
\hline 11 & Institutional & $\begin{array}{l}\text { LA, Local Authority officer responsible for Highways in the geographical area where the PCC } \\
\text { operates. }\end{array}$ \\
\hline 12 & Institutional & $\begin{array}{l}\text { LA, Local Authority officer responsible for the Traffic Division in the geographical area where the } \\
\text { PCC operates. Specific interests include journey time reliability, vehicle mapping, road network } \\
\text { flows and traffic network integration }\end{array}$ \\
\hline 13 & Institutional & $\begin{array}{l}\text { LA, Local Authority officer responsible for Procurement and supplier pre-qualification in the } \\
\text { geographical area where the PCC operates }\end{array}$ \\
\hline 14 & Institutional & LA, Regional business development officer in the geographical area where the PCC operates \\
\hline 15 & Institutional & National funding body officer \\
\hline
\end{tabular}


PPC Figure 1.

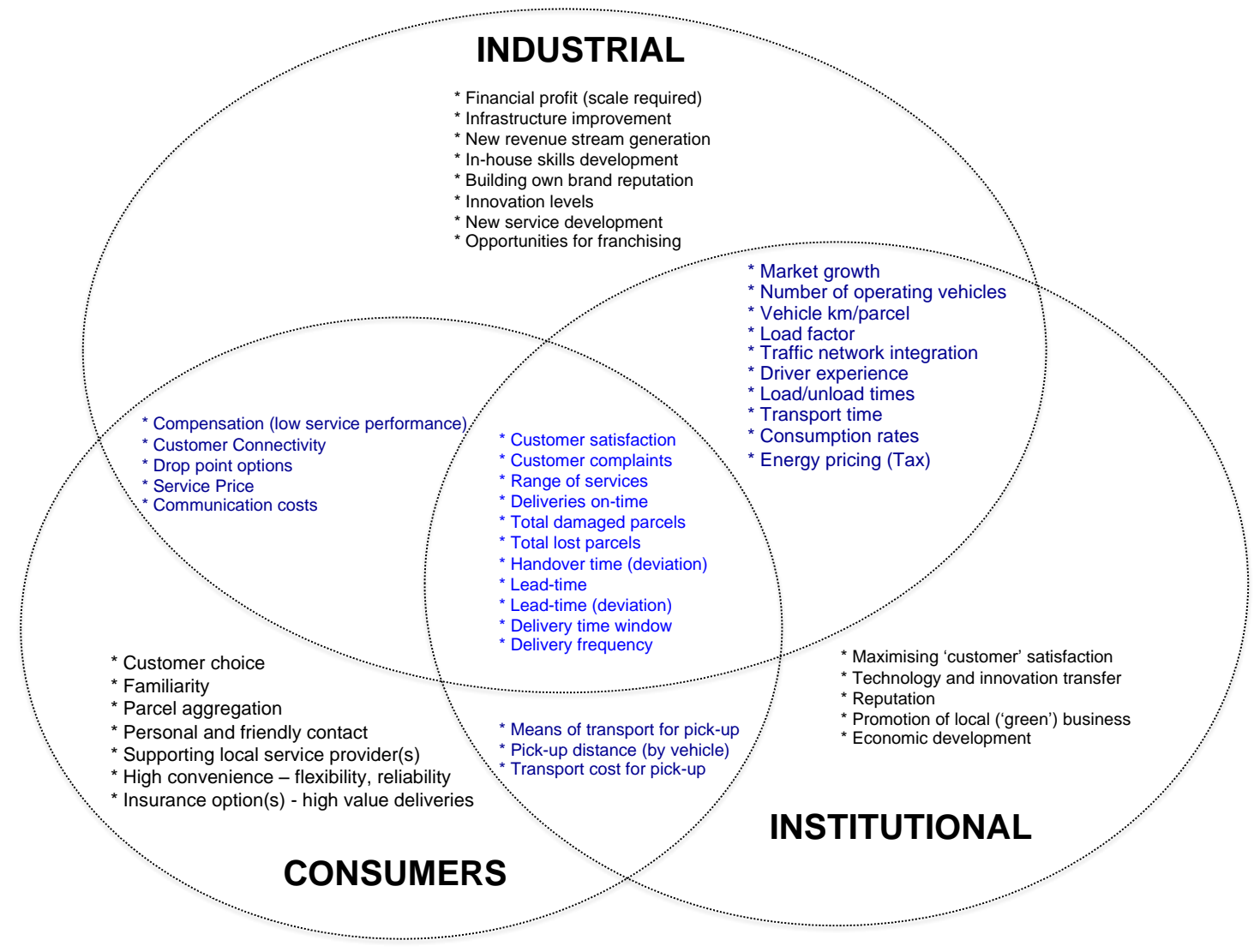

Table 6. 


\section{Consumer Choice Portal-Package Consolidation Centre (CCP-PCC) 'last-mile' solution}

\begin{tabular}{|c|c|c|c|c|c|c|c|}
\hline \multicolumn{2}{|c|}{ Design criteria } & \multicolumn{6}{|c|}{ Service Outcome options } \\
\hline \multirow{12}{*}{ 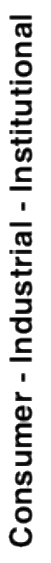 } & \multirow{12}{*}{$\begin{array}{l}\text { Customer satisfaction - no. of attempted deliveries } \\
\text { Customer complaints (Cost, Quality, Time, Flexibility, Reliability) } \\
\text { Range of Services (i.e. 'Green' choice service options) } \\
\text { Range of Services (after-purchase options) } \\
\text { Deliveries on time (OTIF: On-Time and In-Full) } \\
\text { Deliveries on time (\% deliveries on destination route) } \\
\text { Total damaged parcels } \\
\text { Total lost parcels } \\
\text { Handover time (handover time deviation) } \\
\text { Leadtime (leadtime deviation) } \\
\text { Delivery time window } \\
\text { Delivery frequency }\end{array}$} & \multicolumn{2}{|c|}{$>3$} & 3 & 2 & \multicolumn{2}{|c|}{$1^{\star}$} \\
\hline & & \multicolumn{2}{|c|}{$>\mathrm{X}$} & \multicolumn{2}{|c|}{$\mathrm{x}$} & \multicolumn{2}{|c|}{0} \\
\hline & & \multicolumn{3}{|c|}{ 'Green' options not available } & \multicolumn{3}{|c|}{ 'Green' options available * } \\
\hline & & \multicolumn{2}{|c|}{ Not available } & \multicolumn{2}{|c|}{ Assembly } & \multicolumn{2}{|c|}{ Installation } \\
\hline & & \multicolumn{2}{|c|}{$<70 \%$} & \multicolumn{2}{|c|}{$>70 \%$} & \multicolumn{2}{|c|}{$\rightarrow 100 \% *$} \\
\hline & & \multicolumn{2}{|c|}{$<70 \%$} & \multicolumn{2}{|c|}{$>70 \%$} & \multicolumn{2}{|c|}{$\rightarrow 100 \% *$} \\
\hline & & \multicolumn{2}{|c|}{$>5 \%$} & \multicolumn{2}{|c|}{$<5 \%$} & \multicolumn{2}{|c|}{$\rightarrow 0 \%$} \\
\hline & & \multicolumn{2}{|c|}{$>5 \%$} & \multicolumn{2}{|c|}{$<5 \%$} & \multicolumn{2}{|c|}{$\rightarrow 0 \%$} \\
\hline & & $>4$ hours & 4 hours & 3 hours & 2 hours & 1 hour & $<1$ hour \\
\hline & & $>4$ days & 4 days & 3 days & 2 days & 1 day & $<1$ day \\
\hline & & $>4$ hours & 4 hours & 3 hours & 2 hours & & \\
\hline & & & & & & & $y^{*}$ \\
\hline \multirow{9}{*}{ 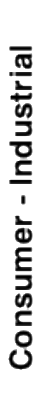 } & Compensation (low service performance) & \multicolumn{3}{|c|}{ Options not available } & & tions avail & \\
\hline & Customer connectivity - information (quality, completeness) & & & Tracking & emand & Track & y notice \\
\hline & Customer connectivity - communication & None & Phone & Fax & Paper & e-mail & SMS \\
\hline & Customer connectivity - contact time & & & $<5$ & & $<1 \min$ & $<10 \mathrm{sec}$ \\
\hline & Drop point options - place of delivery & & & Custome & me * & Pick- & tation * \\
\hline & Drop point options - pay on delivery option & Not & lable & $\mathrm{Ca}$ & & Elec & cally * \\
\hline & Service Price (delivery price) & Price for & ss options & Price per 'Gr & options & Price per $\mathrm{e}$ & lient options \\
\hline & Service Price (pick-up cost ) & Free (pro & onal offer) & $>$ & & & \\
\hline & Communication costs & & (promotion & & & $<\varepsilon X$ & \\
\hline$\frac{1}{0}$ & Means of pick-up & Walking * & Cycling * & Own vehicle* & Taxi & Bus & Other \\
\hline 독 & Pick-up distance & $>50$ & etres & $<500$ & & & \\
\hline 는 & Transport cost for pick-up & & & & & & \\
\hline 0 & High convenience - Accessibility, pick-up window & & Mon-Fri: $7 \mathrm{a}$ & pm; Saturday: & $-6 \mathrm{pm} ; \mathrm{Su}$ & $10 \mathrm{am}-4 \mathrm{p}$ & \\
\hline$\frac{5}{\pi}$ & High convenience - Identification & & & Customer card & & & Biometrics \\
\hline$\overline{\mathbb{C}}$ & High convenience - Attendance (familiarity, personal) & & Unattende & & & Attended & \\
\hline 을 & High convenience - Service centre & & Not availab & & & Available & \\
\hline 至 & Customer choice (portal-enabled) & Acce & ptions & 'Green' & ons * & Expec & options* \\
\hline$\underline{\underline{E}}$ & Customer choice (insurance options for high value deliveries) & & Not availab & & & Available & \\
\hline$\div$ & Parcel aggregation (No. of parcels per delivery) & & $<5^{*}$ & & & $>5$ & \\
\hline$\frac{E}{J}$ & Parcel aggregation (Return shipment) & & Not availab & & & Available & \\
\hline 至 & Parcel aggregation (Allowed parcel weight) & & & Up to & & & \\
\hline $\mathcal{U}$ & Parcel aggregation (Storage/aggregation time) & & & Up to & & & \\
\hline
\end{tabular}

\section{Current levels of service outcome}

Current stage of last mile solution implementation

Targeted last mile solution outcomes *denotes already demonstrated 